\title{
Early Carboniferous sub- to mid-alkaline magmatism in the Eastern Sierras Pampeanas, NW Argentina: A record of crustal growth by the incorporation of mantle-derived material in an extensional setting
}

\author{
P.H. Alasino a,b,*, J.A. Dahlquist ${ }^{\text {b,c }}{ }^{\text {, R.J. Pankhurst }}{ }^{\text {a }}$, C. Galindo ${ }^{\text {e }}$, C. Casquet ${ }^{\text {e }}$, C.W. Rapela ${ }^{\text {f }}$, \\ M.A. Larrovere ${ }^{\mathrm{a}, \mathrm{b}}$, C.M. Fanning ${ }^{\mathrm{g}}$ \\ a CRIIAR-CONICET, Entre Ríos y Mendoza, 5301, Anillaco, La Rioja, Argentin \\ b INGEReN-CENIIT-UNLaR, Av. Gob. Vernet y Apostol Felipe, 5300, La Rioja, Aigentina \\ c CICTERRA-CONICET-UNC, Av. Vélez Sarsfield 1611, Pab. Geol, X5016CGA-Córdoba, Argentina \\ d British Geological Survey, Keywo th, Nottingham NG12 5GG, United Kingdom \\ - Depto. de Petrologín y Geoquímic - IGE (Universidad Complutense, CSIC), 28040 Madrid, Spain \\ ' CIG-CONICET-UNLP, Calle 1 No. 644, 1900, La Plata, Argentina \\ B Research School of Earth Sciences, The Australian National University, Canberra 0200, Australia
}

Keywords:

Early Carboniferous

Sub- to mid-alkaline magmatism

Sierras Pampeanas

Tectonic switching

Western Gondwana margin

\begin{abstract}
A B S T R A C T
A recently discovered granitic intrusion at Cerro La Gloria in western Sierra de Famatina (NW Argentina) is representative of sub- to mid-alkaline Carboniferous magmatism in the region. The main rock type consists of microcline, quartz and plagioclase, with amphibole, magnetite, ilmenite, biotite, epidote, zircon, allanite and sphene as accessory minerals. We report a U-Pb zircon SHRIMP age for the pluton of $349 \pm 3 \mathrm{Ma}$ $(\mathrm{MSWD}=1.1$ ), i.e., Tournaisian. Whole-rock chemical composition and Nd isotope analyses are compatible with an origin by melting of older mafic material in the lower crust ( $\varepsilon$ Ndt between -0.58 and +0.46 and $\mathrm{T}_{\mathrm{M}}$ values of about $1.1 \mathrm{Ga}$ ). The pluton is intruded by penecontemporaneous to late alkaline mafic dykes that are classified as back-arc basalts. Coeval, Early Carboniferous A-type granites occur farther east in the Sierras Pampeanas, probably generated during lithospheric stretching. Overall, the Early Carboniferous granitic rocks show a west-to-east mineralogical and isotopic zonation indicating that magma genesis involved a greater contribution of juvenile material of mantle character to the west. Based on the observed patterns of geochronology, geochemistry and field relationships we suggest that A-type magma genesis in the Eastern Sierras Pampeanas was linked to an Andean-type margin where the lithospheric mantle played a role in its generation.
\end{abstract}

\section{Introduction}

In Carboniferous times, minor but widespread anorogenic magmatism, mainly granitic, occurred along more than $1000 \mathrm{~km}$ in the Sierras Pampeanas of NW Argentina (see Dahlquist et al., 2010, Fig. 1). It is represented by small and scattered plutons, usually sub-circular, intruded mainly along prominent Ordovician shear zones formed during the earlier Famatinian orogeny (e.g., Höckenreiner et al., 2003; Dahlquist et al., 2010). Host rocks to this Carboniferous magmatism formed during three main periods of magmatic and metamorphic activity: Middle Cambrian (Pampean orogeny), Early-Middle Ordovician (Famatinian orogeny), and Middle-Iate Devonian (Achalian event) (Pankhurst et al., 1998; Rapela et al., 1998; Sims et al., 1998; Pankhurst et al., 2000; Dahlquist et al., 2008; Rapela et al., 2008; Vaughan and Pankhurst, 2008; Spagnuolo et al., 2011; Tohver et al., 2011). The geodynamic setting of the Carboniferous magmatism remains controversial. Some authors have suggested that it resulted from crustal reheating as the final phase of a protracted Famatinian orogeny extending from Ordovician to Early Carboniferous (e.g., Grissom et al., 1998; Ilambias et al., 1998; Höckenreiner et al., 2003; Grosse et al., 2009). Others have argued for a distinctive and extended Achalian orogenic event in the DevonianEarly Carboniferous (e.g., Sims et al., 1998; Stuart-Smith et al, 1999; López de Luchi et al., 2004; Siegesmund et al., 2004; Dahlquist et al., 2006; Rapela et al., 2008). Recently, Dahlquist et al. (2010) claimed that the Early Carboniferous A-type granites of the Eastem Sierras Pampeanas represent a tectonothermal event distinct from both Famatinian and Achalian magmatism. Based on lithological variation in the Sierras Pampeanas, Caminos (1979a) was the first to recognise an eastern belt dominated by abundant Palaeozoic granitoids and metasedimentary rocks (the Eastern Sierras Pampeanas), and a western belt characterised by abundant meta-basic, ultrabasic and calc-silicate 


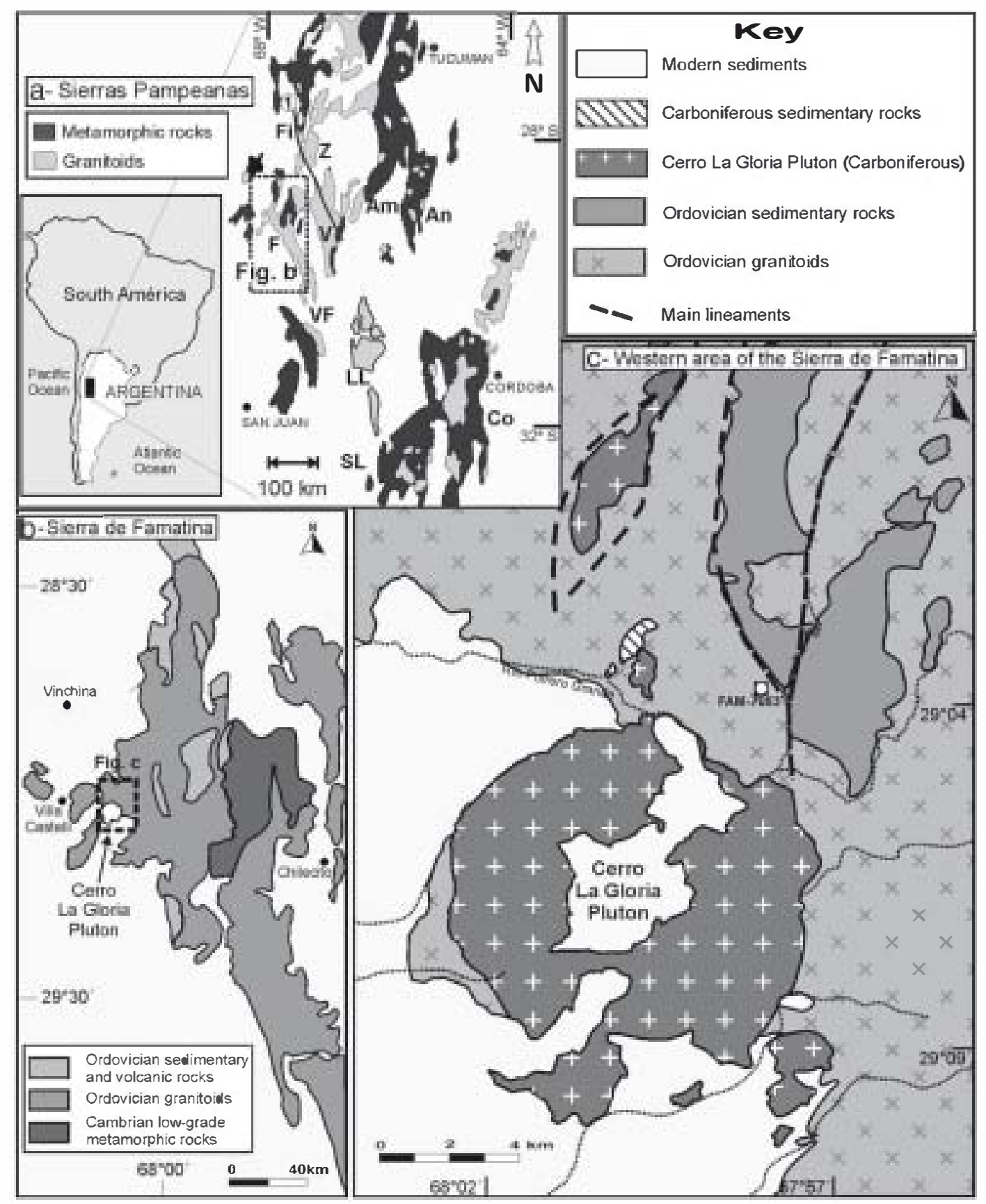

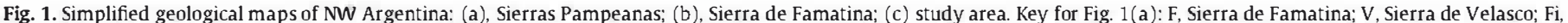

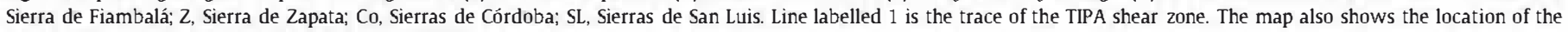
sample (FAM-7083) dated by Dahlquist et al. (2008).

rocks (the Western Sierras Pampeanas). Modern geochronological studies have demonstrated that the Western Sierras Pampeanas preserve a completely different geological history, involving an exposed Mesoproterozoic crystalline basement (e.g., Rapela et al., 2010 and reference therein).

We refer here to a newly discovered intrusion representative of the sub- to mid-alkaline Early Carboniferous magmatism (sensu Rittmann, 1957) at Cerro La Gloria on the western flank of Sierra de Famatina. The information gathered from this pluton, along with that from other Late Palaeozoic intrusions, is used to constrain their geotectonic setting. We conclude that this Early Carboniferous magmatism in the Eastem Sierras Pampeanas formed in an extensional, ensialic region closely linked to an Andean-type margin and that lithospheric mantle played a role in the magma generation.

\section{Geological setting}

The Sierra de Famatina is located at $29^{\circ} \mathrm{S}$ in La Rioja province, northwestern Argentina (Fig. 1). It has an overall length of $\mathrm{c}$. $250 \mathrm{~km}$ and a maximum altitude of $6250 \mathrm{~m}$ above sea level. Its geology is characterised by widespread Ordovician plutonic rocks and local volcanic and sedimentary outcrops of the same age (for reviews see Aceñolaza et al., 1996; Saavedra et al., 1998a; Astini et al., 2007; Dahlquist et al., 2008 and references therein). Well-exposed sections across the belt show transition from mid-crustal levels in the west (mafic to intermediate plutonic rocks hosted by migmatitic gneisses and amphibolites) to shallow levels in the centre and the east (acidic plutonic and volcanic rocks and low- to very low-grade metamorphic rocks such as phyllite, metapsammite and chert). The Sierra de 
Famatina, like other Sierras Pampeanas, is crossed by prominent shear zones that overprint all these rock types (e.g., Conci et al., 2001).

The Cerro La Gloria pluton is circular, with a radius of $5 \mathrm{~km}$ and an area of c. $80 \mathrm{~km}^{2}$ (Fig. 1b-c). Topographic relief is higher around the rim, hampering access to the pluton core. Contacts with the surrounding Early Ordovician plutonic rocks are sharp and irregular on a local scale (Fig. 2a). The main plutonic facies is pink-to-red, porphyritic to inequigranular, medium- to coarse-grained syenogranite (Fig. 2b). Planar minerals such as mica are scarce, which makes it difficult to recognise internal orientation in the field. Some cm-size mafic microgranular enclaves show ovoid and square forms (Fig. 2b).

The host Ordovician plutonic rocks are of two types. Most common is the Nuñorco granite (Toselli et al., 1996; Dahlquist et al., 2008), a biotite granodiorite to monzogranite of regional extent; along the western flank of the Sierra de Famatina it exhibits an Ordovician N-S trending penetrative mylonitic foliation. The other wall-rock is a hornblende-bearing tonalite belonging to the Cerro Toro complex (Saavedra et al., 1998a). Subvertical rhyolitic or trachytic dykes occur locally in both wall-rocks, and these dykes vary from $0.5 \mathrm{~m}$ to $30 \mathrm{~m}$ thick and trend $\mathrm{N} 245^{\circ}$ to $\mathrm{N} 310^{\circ}$ (Fig. 2c). The subvertical

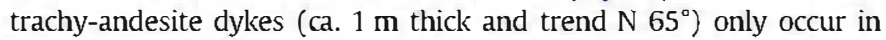
the studied pluton.

\section{Analytical methods}

Forty-eight samples were collected for petrographic study. Major and trace elements were determined on 9 representative whole-rock powders by ICP-OES and ICP-MS at ACГIABS, Canada (4-lithoresearch code procedure). Samples are first fused with lithium metaborate/tetraborate and then dissolved in a nitric acid solution. Major elements, Be, $\mathrm{Sc}, \mathrm{V}, \mathrm{Sr}, \mathrm{Ba}$, and $\mathrm{Zr}$ are determined by Inductively Couple Plasma-Optical Emission Spectroscopy; all other trace elements are determined by Inductively Coupled Plasma-Mass Spectrometry. Precision and accuracy for major elements are generally better than $2 \%$ (relative); for trace elements they are generally better than $\pm 6 \%$ when signals are 10 times above background. Additionally, two representative igneous samples were determined by GeoAnalytical Iab, Washington State University, using a ThermoARL sequential X-ray fluorescence spectrometer, following the procedure described by Johnson et al. (1999).

Mineral compositions were determined using a JEOL Superprobe JXA-8900-M equipped with five crystal spectrometers at the Luis Brú Electron Microscopy Center, Complutense University, Madrid, Spain. Operating conditions were: acceleration voltage $15 \mathrm{kV}$, probe current $20 \mathrm{nA}$, beam diameter 1-2 $\mu \mathrm{m}$. Absolute abundances for each element were determined by comparison with standards (Jarosewich et al., 1980; McGuire et al., 1992), using an on-line ZAF programme.

Sm-Nd analyses of three representative samples were carried out at the Geochronology and Isotope Geochemistry Center, Complutense University (Madrid, Spain) using an automated multicollector VGB SECIOR 54 mass spectrometer. Errors are quoted throughout as two standard deviations from measured or calculated values. Analytical uncertainties are estimated to be $0.006 \%$ for ${ }^{143} \mathrm{Nd} /{ }^{141} \mathrm{Nd}$ and $0.1 \%$

${ }^{147} \mathrm{Sm} /{ }^{141} \mathrm{Nd}$. Fifty-six analyses of La Jolla Nd-standard over year gave a mean ${ }^{143} \mathrm{Nd} /{ }^{141} \mathrm{Nd}$ ratio of $0.511846 \pm 0.00003$.

\section{Petrographic characteristics and mineral composition}

The Cerro La Gloria granitoid consists of microcline (43-49 modal $\%)$, quartz (32-41 modal \%) and plagioclase (11-16 modal \%) $(n=4)$. Representative compositions of minerals are found in Supplementary data. Microcline $\left(A b_{7.8}-A n_{<0.1}-O r_{92} ; n=2\right)$ is perthitic coarse- to medium-grained, subhedral to anhedral, with inclusions of plagioclase, biotite, quartz, zircon, epidote and oxides. Perthite is $\mathrm{Ab}_{97}-\mathrm{An}_{3.1}-\mathrm{Or}_{0.8}$ $(\mathrm{n}=2)$. Microcline is interstitial relative to quartz, and a probably subsolidus albitic rim $\left(\mathrm{Ab}_{95-99}-\mathrm{An}_{0.2-4.4}-\mathrm{Or}_{0.1-1.4}\right)$ is found around microcline crystals in contact with plagioclase. Plagioclase $\left(\mathrm{Ab}_{88-95}-\mathrm{An}_{3.6-9.4}-\mathrm{Or}_{0.8-2.1}\right)$ is medium-grained, subhedral, often corroded and fractured. Quartz crystals are irregular in form, although at
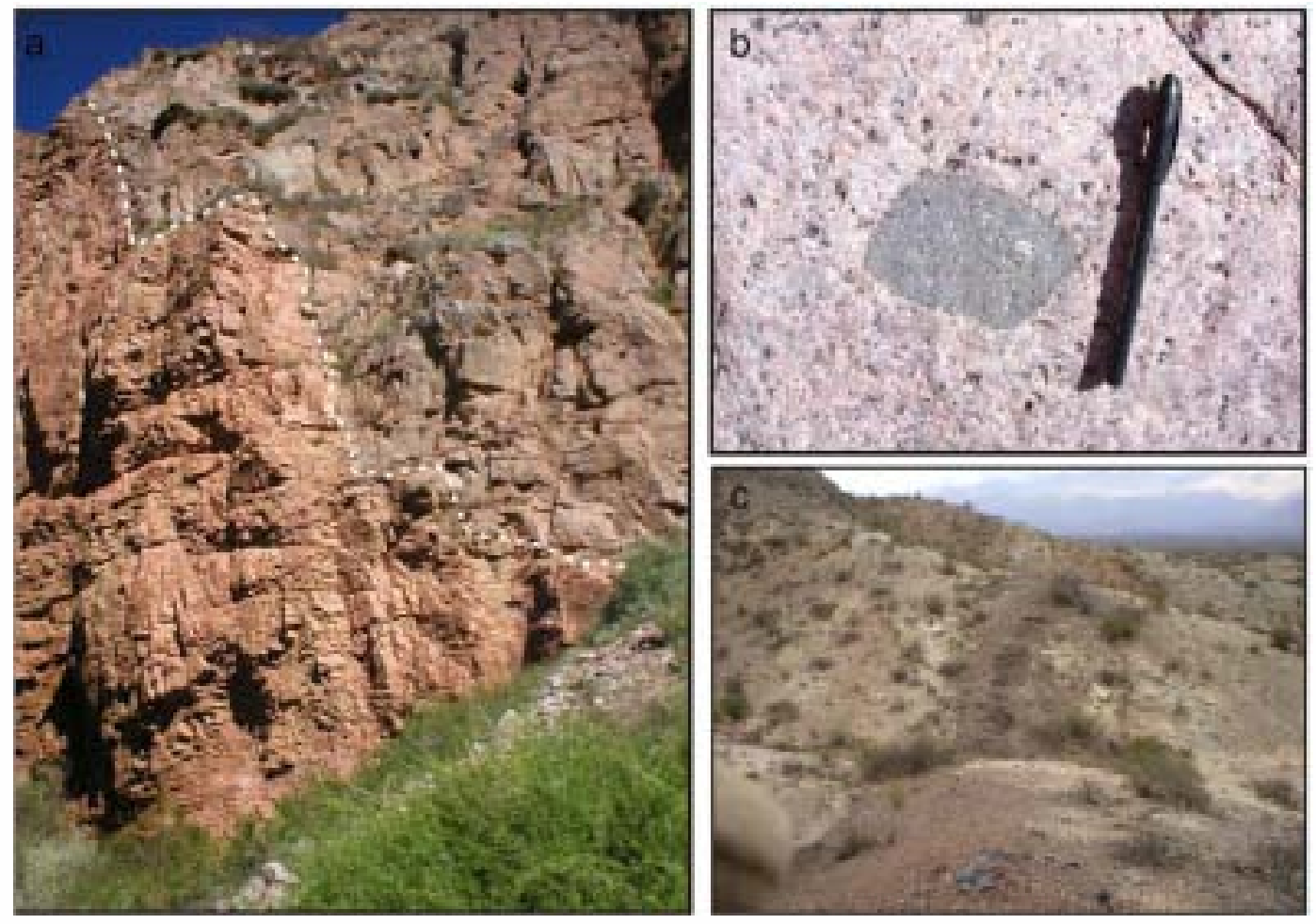

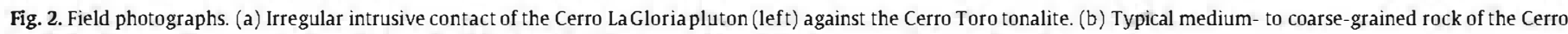
La Gloria pluton, with a mafic enclave. (c) Rhyolite dyke intruding the Ordovician wall-rock, western Sierra de Famatina. 
Table 1

Representative major and trace element whole-rock data for the Cerro La Gloria pluton, dykes and wall-rocks.

\begin{tabular}{|c|c|c|c|c|c|c|c|c|c|c|c|}
\hline \multirow{2}{*}{$\frac{\text { Unit }}{\text { Sample }}$} & \multicolumn{6}{|c|}{ Cerro La Gloria pluton } & \multicolumn{4}{|l|}{ Dykes } & \multirow{2}{*}{$\frac{\text { Wall rock }}{\text { FAM }}$} \\
\hline & FAM & FAM & FAM & CLG & CLG & FMM & FAM & FAM & FAM & FAM & \\
\hline & $177^{*}$ & $178^{*}$ & $180^{*}$ & $125^{*}$ & $126^{*}$ & $307+$ & $308^{+}$ & $148^{*}$ & $151^{*}$ & $155^{*}$ & $192^{*}$ \\
\hline \multicolumn{12}{|l|}{$w t . \%$} \\
\hline $\mathrm{SiO}_{2}$ & 75.05 & 82.61 & 78.00 & 77.93 & 77.41 & 75.62 & 54.97 & 62.84 & 76.52 & 76.64 & 73.21 \\
\hline $\mathrm{TiO}_{2}$ & 0.21 & 0.06 & 0.11 & 0.07 & 0.08 & 0.15 & 1.98 & 0.51 & 0.09 & 0.09 & 0.28 \\
\hline $\mathrm{Al}_{2} \mathrm{O}_{3}$ & 12.66 & 9.17 & 11.26 & 12.30 & 11.58 & 12.98 & 16.03 & 15.58 & 11.78 & 12.03 & 12.85 \\
\hline $\mathrm{Fe}_{2} \mathrm{O}_{3}$ & 2.13 & 1.08 & 1.89 & 1.44 & 1.75 & 1.58 & 12.41 & 5.27 & 1.75 & 1.74 & 2.84 \\
\hline $\mathrm{MnO}$ & 0.03 & 0.01 & 0.03 & 0.03 & 0.01 & 0.03 & 0.18 & 0.14 & 0.02 & 0.02 & 0.06 \\
\hline $\mathrm{MgO}$ & 0.18 & bdI & 0.04 & 0.03 & 0.06 & 0.10 & 1.87 & 0.48 & 0.03 & 0.02 & 0.61 \\
\hline $\mathrm{CaO}$ & 0.83 & 0.16 & 0.35 & 0.43 & 0.31 & 0.60 & 3.94 & 2.09 & 0.69 & 0.50 & 1.65 \\
\hline $\mathrm{Na}_{2} \mathrm{O}$ & 3.59 & 3.18 & 3.72 & 3.73 & 3.75 & 4.01 & 5.26 & 4.55 & 3.90 & 3.78 & 3.83 \\
\hline $\mathrm{K}_{2} \mathrm{O}$ & 5.03 & 3.54 & 4.62 & 4.5 & 4.29 & 5.06 & 3.22 & 5.29 & 4.16 & 4.62 & 3.02 \\
\hline $\mathrm{P}_{2} \mathrm{O}_{5}$ & 0.04 & 0.01 & 0.02 & 0.02 & 0.02 & 0.03 & 1.37 & 0.18 & 0.02 & 0.01 & 0.06 \\
\hline LOI & 0.19 & 0.16 & 0.15 & 0.32 & 0.36 & 0.21 & 2.08 & 1.01 & 0.97 & 1.08 & 0.84 \\
\hline Total & 99.94 & 99.98 & 100.2 & 100.8 & 99.62 & 99.18 & 98.49 & 97.94 & 99.93 & 100.53 & 99.26 \\
\hline \multicolumn{12}{|l|}{ ppm } \\
\hline $\mathrm{Be}$ & 3 & 3 & 4 & 6 & 6 & - & - & 4 & 4 & 5 & 3 \\
\hline $\mathrm{Sc}$ & 4 & $<1$ & 2 & 1 & $<1$ & 2.7 & 22.6 & 12 & L & 1 & 11 \\
\hline $\mathrm{Cr}$ & $<20$ & $<20$ & $<20$ & 30 & $<20$ & $<20$ & $<20$ & $<20$ & 39 & $<20$ & $<20$ \\
\hline $\mathrm{Ni}$ & $<20$ & $<20$ & $<20$ & $<20$ & $<20$ & $<20$ & $<20$ & $<20$ & $<20$ & $<20$ & $<20$ \\
\hline $2 n$ & 41 & $<30$ & 51 & 30 & 90 & 45 & 279 & 121 & 67 & 120 & $<30$ \\
\hline Cs & 1.5 & 1.5 & 1.1 & 4.3 & 2.9 & 1.3 & 1.6 & 1.43 & 1.1 & 1.17 & 1.9 \\
\hline $\mathrm{Rb}$ & 107 & 104 & 111 & 269 & 186 & 131 & 118 & 117 & 162 & 166 & 107 \\
\hline $\mathrm{Sr}$ & 65 & 4 & 10 & 6 & 5 & 44 & 361 & 70 & 15 & 16 & 110 \\
\hline $\mathrm{Ba}$ & 448 & 16 & 49 & 23 & 16 & 253 & 797 & 942 & 13 & 26 & 494 \\
\hline La & 84.1 & 67.5 & 95.0 & 32.2 & 49.8 & 52.7 & 94.2 & 174 & 73.0 & 70.3 & 27.4 \\
\hline $\mathrm{Ce}$ & 175 & 153 & 206 & 79.4 & 108 & 106 & 188 & 314 & 154 & 149 & 60.9 \\
\hline $\operatorname{Pr}$ & 17.1 & 14.6 & 21.3 & 9.89 & 12.5 & 12.1 & 23.6 & 30.9 & 16.4 & 16.0 & 6.41 \\
\hline Nd & 53.5 & 46.6 & 71.1 & 41.8 & 50 & 42.6 & 93.2 & 107 & 59.2 & 57.8 & 22.9 \\
\hline $\mathrm{Sm}$ & 9.47 & 8.78 & 13.8 & 10.5 & 12.1 & 9.32 & 18.8 & 16.4 & 13.22 & 13.11 & 4.99 \\
\hline Eu & 0.94 & 0.17 & 0.29 & 0.14 & 0.12 & 0.65 & 5.52 & 3.34 & 0.06 & 0.06 & 0.96 \\
\hline Gd & 7.39 & 7.10 & 11.3 & 12.1 & 13.5 & 8.41 & 16.9 & 11.2 & 11.0 & 10.9 & 4.78 \\
\hline $\mathrm{Tb}$ & 1.15 & 1.20 & 1.80 & 2.41 & 2.63 & 1.43 & 2.62 & 1.75 & 1.96 & 1.96 & 0.90 \\
\hline Dy & 5.71 & 6.36 & 9.34 & 15.5 & 16.8 & 8.58 & 15.3 & 9.58 & 10.8 & 10.9 & 5.07 \\
\hline Ho & 1.06 & 1.28 & 1.84 & 3.13 & 3.23 & 1.70 & 3.00 & 1.84 & 2.18 & 2.18 & 1.07 \\
\hline $\mathrm{Er}$ & 3.16 & 4.22 & 5.66 & 8.73 & 8.8 & 4.54 & 7.96 & 5.76 & 6.74 & 6.85 & 3.47 \\
\hline $\operatorname{Tm}$ & 0.46 & 0.689 & 0.88 & 1.30 & 1.23 & 0.66 & 1.11 & 0.87 & 1.07 & 1.04 & 0.58 \\
\hline $\mathrm{Yb}$ & 2.77 & 4.06 & 5.19 & 8.32 & 7.5 & 4.05 & 6.82 & 5.55 & 6.25 & 6.36 & 3.60 \\
\hline $\mathrm{Lu}$ & 0.39 & 0.55 & 0.72 & 1.21 & 1.04 & 0.63 & 1.05 & 0.90 & 0.98 & 0.97 & 0.51 \\
\hline $\mathrm{U}$ & 1.90 & 2.08 & 2.49 & 5.35 & 4.61 & 3.02 & 4.30 & 4.38 & 7.04 & 6.68 & 2.69 \\
\hline Th & 17.0 & 16.4 & 22.1 & 47.7 & 24.5 & 18.4 & 10.9 & 22.2 & 34.9 & 35.0 & 12.9 \\
\hline $\mathrm{Y}$ & 26.9 & 33.5 & 45.9 & 81.8 & 82.3 & 41.8 & 76.6 & 44.1 & 51.7 & 52.0 & 27.5 \\
\hline $\mathrm{Nb}$ & 15.6 & 14.9 & 23.1 & 34.4 & 29 & 20.1 & 45.5 & 50.3 & 40.7 & 42.6 & 10.3 \\
\hline $\mathrm{Zr}$ & 191 & 168 & 221 & 130 & 199 & 246 & 635 & 1010 & 246 & 215 & 139 \\
\hline $\mathrm{Hf}$ & 5.8 & 5.9 & 7.3 & 5.5 & 7.40 & 6.75 & 13.5 & 23.4 & 9.12 & 8.47 & 4.40 \\
\hline $\mathrm{Ta}$ & 0.78 & 1.21 & 1.64 & 4.21 & 2.76 & 1.40 & 2.81 & 3.11 & 3.01 & 3.12 & 0.85 \\
\hline $\mathrm{Pb}$ & 25 & 26 & 26 & 20 & 52 & 23.2 & 50.1 & 10.7 & 26.2 & 19.6 & 16 \\
\hline $\mathrm{Ga}$ & 19 & 18 & 23 & 24 & 25 & 19 & 20 & 25 & 23 & 24 & 15 \\
\hline $\mathrm{M}$ & 1.44 & 1.30 & 1.42 & 1.32 & 1.34 & 1.44 & 2.35 & 1.81 & 1.43 & 1.41 & 1.40 \\
\hline $\mathrm{T}_{2 \mathrm{r}}{ }^{\circ} \mathrm{C}$ & 799 & 798 & 813 & 774 & 810 & 822 & - & - & 823 & 812 & 777 \\
\hline
\end{tabular}

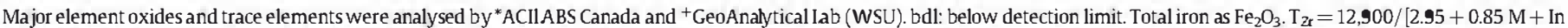

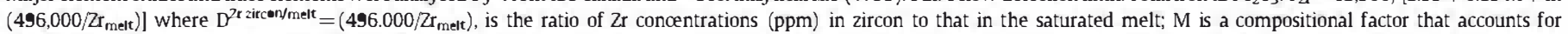

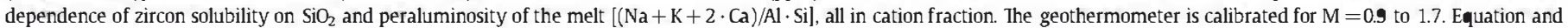
$\mathrm{Zr}$ concentrations (ppm) in zircon ( $=496,000 \mathrm{ppm}$ ) are from Miller et aL (2003).

the edge of the pluton they occur as hexagonal grain aggregates, and probably underwent some static recrystallisation. It usually shows fractures. Zircon inclusions are locally found in quartz. Accessory minerals ( $<2$ modal \%) are amphibole, magnetite, ilmenite, biotite, epidote, zircon, allanite and sphene. Biotite is medium- to coarse-grained, subhedral to anhedral, with magnesium-number (Mg\#) around 16, although corroded crystals are richer in Fe-annite (Mg\# about 4.8). Amphibole is not found in all samples, but where it does occur, it is medium- to fine-grained, dark green to dark brown, with Mg\# values of c. 15. As with corroded biotite, corroded amphibole crystals, i.e., those showing less pleochroism and associated with biotite laths together with an epidote rim, have lower Mg\# values (3.2-3.9). Primary amphibole is Ferro-edenite according to the Leake et al. (1997) classification $\left[\mathrm{Ca}_{\mathrm{B}}=1.80-1.81\right.$ a.p.f.u.; $(\mathrm{Na}+\mathrm{K})_{\mathrm{A}}=0.70-0.74$ atoms per formula unit (a.p.f.u.) and $\mathrm{Ti}=0.17-0.19$ a.p.f.u.]. Primary ore minerals are magnetite and ilmenite. Some samples exhibit fractures filled by a fine-grained matrix of biotite, muscovite, epidote, titanite and ore minerals.

Microgranular mafic enclaves consist of oligoclase, K-feldspar, biotite, amphibole, apatite and ore minerals (one analysed grain is ilmenite). Mafic minerals are relatively rich in $\mathrm{Mg}$ with \#Mg values of 36 and 28 for biotite and amphibole, respectively. Amphibole is ferroedenite. Sometimes the enclaves have olivine, with a skeletal or euhedral form.

The essential mineralogy of the host rocks is plagioclase, quartz, microcline and biotite in the Ñuñorco granite and plagioclase, quartz, biotite, and hornblende in the Cerro Toro tonalite. Both show a weak brittle deformation as micro-cracks in primary minerals (mainly 


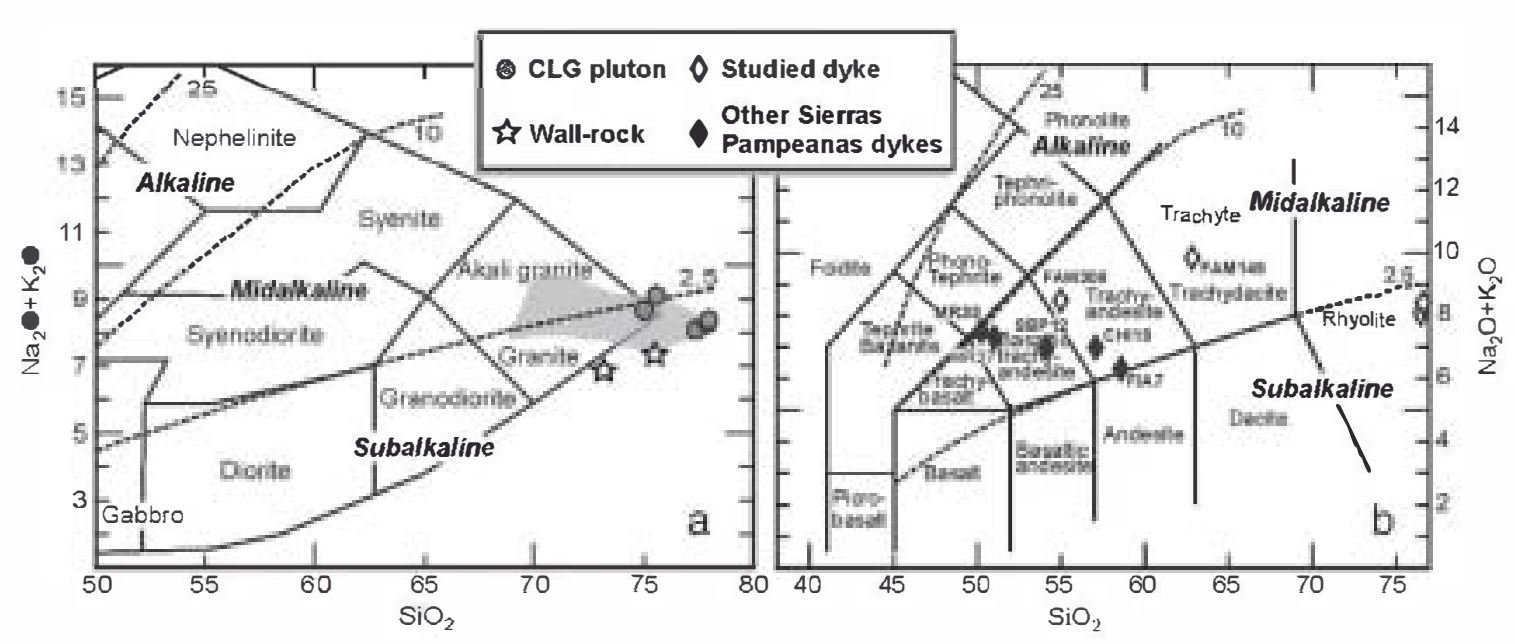

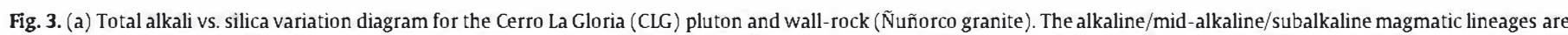

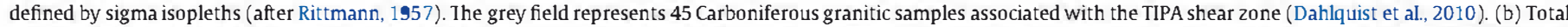

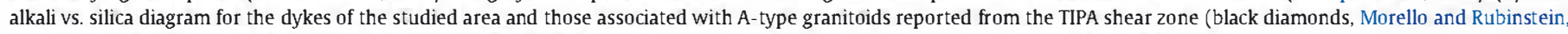
2000; Dahlquist et al., 2010; white diamonds this work). The diagram also shows sigma isopleths. FAM-178 ( $\left.\mathrm{SiO}_{2}>82 \%\right)$ is not plotted.

quartz and feldspar). The cracks are often filled with biotite, muscovite, epidote and some sphene, similar to those found in the pluton and probably of deuteric solution origin.

The dykes are porphyritic. Differentiated types (e.g., FAM-151 and FAM-155) found in wall-rocks around the pluton are generally pink in colour, contain euhedral quartz and feldspar phenocrysts (around $3 \mathrm{~mm}$ size) in a very fine-grained ( $<0.1 \mathrm{~mm}$ ) intergranular to vitrophyric groundmass. Spherulitic texture is locally found. Among the less differentiated dykes FAM-148 has porphyritic texture with phenocrysts (c. $2 \mathrm{~mm}$ ) of plagioclase, oxides and minor quartz; the plagioclase phenocrysts often show sieve texture, and the groundmass consists of plagioclase laths, oxides and phyllosilicate (commonly chlorite). The least siliceous dyke cutting the CLG pluton itself (FAM-308) is fine-grained and consists of plagioclase, biotite, oxides, and apatite.

\section{Whole rock chemical composition}

Major- and trace-element compositions of six representative samples of the Cerro La Gloria pluton, one of the Nuñorco granite wallrock, and four dykes are presented in Table 1. Most of these samples are from the northern region of the pluton. One additional wholerock analysis of the wall-rock (FAM-7083, Nuñorco granite -
Fig. 1c) is included from Dahlquist et al. (2008), who reported its age as $463 \pm 4 \mathrm{Ma}$ (U-Pb SHRIMP on zircon).

\subsection{Major elements}

The Cerro La Gloria granitic rocks are felsic or evolved in composition; $\mathrm{SiO}_{2}$ content varies within a restricted range from 75.05 to $82.61 \%$ (Table 1). In the alkalis vs. silica classification diagram, the compositions plot close to the limit between alkali granite and granite (Fig. 3a); some fall in the subalkaline field but the less silica-rich samples plot across the limit with the mid-alkaline lineage of Rittmann (1957), defined by a sigma index of $2.5\left[\sigma=\left(\mathrm{Na}_{2} \mathrm{O}+\mathrm{K}_{2} \mathrm{O}\right)^{2} /\right.$ $\left.\left(\mathrm{SiO}_{2}-43\right)\right]$. The granitic samples have sigma values from 1.9 to 2.5 , similar to other Early Carboniferous granitoids from the Sierras Pampeanas. They are metaluminous to slightly peraluminous (aluminium saturation index, ASI $=0.96-1.05$ ), although they have a relatively high agpaitic index $(\mathrm{AI}=0.90-0.98)$. They also are poor in $\mathrm{CaO}$ $(0.31-0.83 \%)$ and extremely rich in $\mathrm{FeO}^{\mathrm{t}}$ relative to $\mathrm{MgO}$ with high $\mathrm{FeO}^{\mathrm{t}} /\left(\mathrm{FeO}^{\mathrm{t}}+\mathrm{MgO}\right)$ ratios $(0.91-1.00)$. They are enriched in $\mathrm{TiO}_{2}$ relative to $\mathrm{MgO}\left(\mathrm{TiO}_{2} / \mathrm{MgO}>1\right)$ and they are moderately enriched in total alkalis (8.04-8.72\%), with relatively high $\mathrm{K}_{2} \mathrm{O}$ content $\left(\mathrm{K}_{2} \mathrm{O} / \mathrm{Na}_{2} \mathrm{O}=1.11-1.40\right)$.

In contrast, the Ordovician wall-rock samples plot below the granite field and subalkaline lineage with sigma values of 1.5 and 1.7 (Fig. 3a). They have $\mathrm{SiO}_{2}$ contents of 73.2 and $75.6 \%$ with

Table 2

Main features of the dykes of the Sierras Pampeanas included in this work.

\begin{tabular}{|c|c|c|c|c|c|}
\hline $\begin{array}{l}\text { Longitude } \\
\text { location }\end{array}$ & Name & Field relationships & $\begin{array}{l}\mathrm{SiO}_{2} \\
(w \mathrm{wt. \%})\end{array}$ & TAS classification & $\begin{array}{l}\text { Chemical } \\
\text { features }\end{array}$ \\
\hline $67^{\circ} 57^{\prime}$ & $\begin{array}{l}\text { FAM } 308 \text {, Sierra de Famatina (this } \\
\text { work) }\end{array}$ & $\begin{array}{l}\text { Dyke } \sim 1 \mathrm{~m} \text { wide trending } \sim 65^{\circ} \text { intruding the Cerro La Gloria } \\
\text { pluton. }\end{array}$ & -55 & Trachy-andesite & $\begin{array}{l}\mathrm{ASI}=0.99 \\
\mathrm{La} / \mathrm{Yb}_{N}=\mathbf{9} .2 \\
\mathrm{Eu} / \mathrm{Eu}^{*}=0.95\end{array}$ \\
\hline $67^{\circ} 32^{\prime}$ & $\begin{array}{l}\text { FIA7, Sierra de Fiambalá } \\
\text { (Dahlquist et al., 2010) }\end{array}$ & $\begin{array}{l}\text { Dyke }-2 \mathrm{~m} \text { wide trending }-345^{\circ} \text { intruding the Ios Árboles } \\
\text { pluton. }\end{array}$ & -59 & Trachy-andesite & $\begin{array}{l}\mathrm{ASI}=0.91 \\
\mathrm{La} / \mathrm{Yb}_{N}=6.5 \\
\mathrm{Eu} / \mathrm{Eu}^{*}=0.50\end{array}$ \\
\hline $67^{\circ} 32^{\prime}$ & $\begin{array}{l}\text { MR27 and 33, Sierra de Fiambalá } \\
\text { (Morello and Rubinstein, 2000) }\end{array}$ & $\begin{array}{l}\text { Dykes }<4 \mathrm{~m} \text { wide trending } 40^{\circ} \text { to } 90^{\circ} \mathrm{E} \text { intruding the Los Árboles } \\
\text { pluton. }\end{array}$ & 50 to 51 & $\begin{array}{l}\text { Basaltic trachy- } \\
\text { andesite }\end{array}$ & $\begin{array}{l}\mathrm{ASI}=0.81-1.03 \\
\mathrm{La} / \mathrm{Yb}_{N}=7.5- \\
10.4 \\
\mathrm{Eu} / \mathrm{Eu}^{*}=0.61- \\
0.71\end{array}$ \\
\hline $67^{\circ} 07^{\prime}$ & $\begin{array}{l}\text { SBP12, Sierra de Velasco } \\
\text { (Dahlquist et al., 2010) }\end{array}$ & Dyke $-3.5 \mathrm{~m}$ wide trending $\sim 340^{\circ}$ intruding the San Blas pluton. & -54 & $\begin{array}{l}\text { Basaltic trachy- } \\
\text { andesite }\end{array}$ & $\begin{array}{l}\mathrm{ASI}=0.89 \\
\mathrm{La} / \mathrm{Yb}_{\mathrm{N}}=7.6 \\
\mathrm{Eu} / \mathrm{Eu}^{*}=0.75\end{array}$ \\
\hline $66^{\circ} 58^{\prime}$ & $\begin{array}{l}\text { CHI19, Sierra de Velasco } \\
\text { (Dahlquist et al., 2010) }\end{array}$ & Dyke $-2 \mathrm{~m}$ wide trending $-20^{\circ}$ intruding the Huaco pluton. & -57 & Trachy-andesite & $\begin{array}{l}\mathrm{ASI}=0.91 \\
\mathrm{La} / \mathrm{Yb}_{N}=10.1 \\
\mathrm{Eu} / \mathrm{Eu}^{*}=0.95\end{array}$ \\
\hline
\end{tabular}




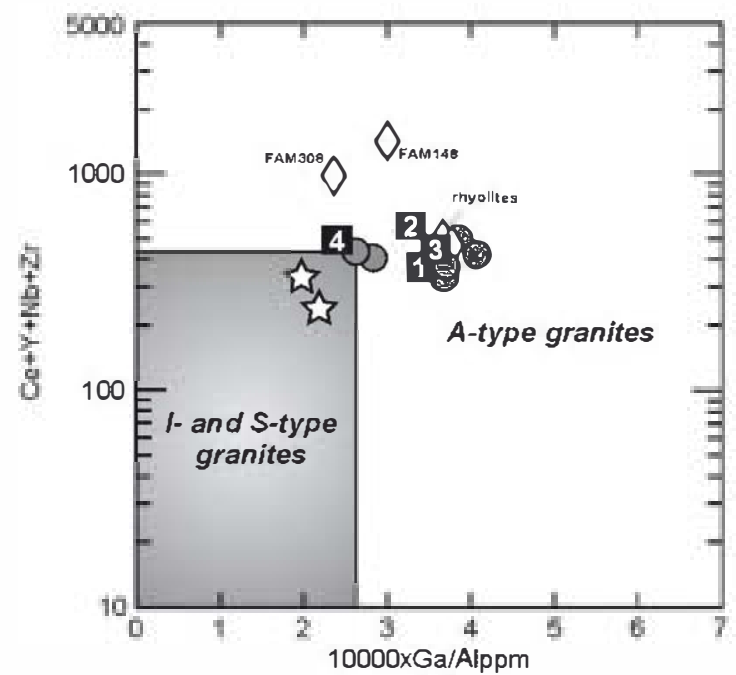

Fig. 4. $\mathrm{Ce}+\mathrm{Nb}+\mathrm{Zr}+\mathrm{Y}$ vs. $10,000 \times \mathrm{Ga} / \mathrm{Al}$ granite discrimination diagram (Whalen et aL, 1987). Symbols are as in Fig. 3. Labelled squares 1, 2 and 3 are averages of A-type granitoids from Konopelko et al. (2007), Chappell and White (1992) and Dahlquist et al. (2010), respectively; 4 corresponds to the average for dykes from TIPA shear zone (Morello and Rubinstein, 2000; Dahlquist et al., 2010).

relatively lower ratios of $\mathrm{FeO}^{\mathrm{t}} /\left(\mathrm{FeO}^{\mathrm{t}}+\mathrm{MgO}\right)=0.81$ and $0.90, \mathrm{TiO}_{2} /$ $\mathrm{MgO}=0.46$ and 0.84 , and low total alkali contents (6.85 and 7.38\%) but with high $\mathrm{Na}_{2} \mathrm{O}\left(\mathrm{K}_{2} \mathrm{O} / \mathrm{Na}_{2} \mathrm{O}=0.79\right.$ and 0.89$)$. Like the Cerro La Gloria granites, they are metaluminous to slightly peraluminous $(A S I=1.03-1.05)$, but with a lower agpaitic index $(\mathrm{AI}=0.74-0.81)$.

In terms of alkalis vs. silica (Fig. 3b), the dykes are classified as (i) rhyolites with $76.6 \% \mathrm{SiO}_{2}$ and sigma indices of 1.95 and 2.10 (FAM-151 and FAM-155, respectively) and (ii) trachyandesite to trachyte with $54.97-62.84 \% \mathrm{SiO}_{2}$ and sigma indices of 6.00 and 4.88 (FAM-308 and FAM-148, respectively). The rhyolites show similar geochemical features to the Cerro Ia Gloria granite samples (Table 1). They are metaluminous with high ASI (0.97-0.99) and AI (0.93). They are poor in $\mathrm{CaO}(0.50-0.69 \%)$ and extremely rich in $\mathrm{FeO}^{\mathrm{t}}$ and $\mathrm{TiO}_{2}$, with $\mathrm{FeO}^{\mathrm{t}} /\left(\mathrm{FeO}^{\mathrm{t}}+\mathrm{MgO}\right)=0.98-0.99$ and $\mathrm{TiO}_{2} /$ $\mathrm{MgO}>1$; they are moderately rich in total alkalis (8.06-8.40\%), with relatively high $\mathrm{K}_{2} \mathrm{O}$ content $\left(\mathrm{K}_{2} \mathrm{O} / \mathrm{Na}_{2} \mathrm{O}=1.07-1.22\right)$. The less siliceous dykes are also metaluminous (ASI-AI 0.99-0.76 for trachyandesite and 0.94-0.85 for trachyte) with high $\mathrm{CaO}$ (3.94 and 2.09\%) compared to the rhyolites, although the $\mathrm{FeO}^{\mathrm{t}} / \mathrm{MgO}(0.86$ and 0.92 ) and $\mathrm{TiO}_{2} / \mathrm{MgO}$ (1.05 and 1.06, respectively) ratios are similar. They have a high total alkalis (8.48-9.84\%) even exceeding that of the rhyolites, although $\mathrm{K}_{2} \mathrm{O}$ content is high for the trachyte but low for the rachyandesite $\left(\mathrm{K}_{2} \mathrm{O} / \mathrm{Na}_{2} \mathrm{O}=1.16\right.$ and 0.61 , respectively). Our dyke samples and those associated with the Carboniferous A-type granitoids, such as the San Blas, Huaco and Los Árboles plutons that crop out in the Sierras de Velasco and Fiambalá (Figs. 1 and 11, and Table 2), show a similar mid-alkaline lineage (Fig. 3b).

\subsection{Trace elements}

The concentration ranges for high field-strength elements (HFSE) such as Y, Nb, Ga, Ta and Th are relatively high (Table 1) and they are comparable to those of other Carboniferous A-type granites in the proto-Andean foreland in Argentina (e.g., Dahlquist et al., 2010) as well as those of the Lachlan Fold Belt in Australia (Chappell and White, 1992) or the Hercynian A-type granites of the Kokshaal range in Kyrgyzstan (Konopelko et al., 2007). All studied plutonic samples (except for the wall-rock samples) exceed the limiting values of $\mathrm{Ce}+\mathrm{Nb}+\mathrm{Zr}+\mathrm{Y}$ and $10,000 * \mathrm{Ga} / \mathrm{Al}$ proposed by Whalen et al. (1987) and consequently plot in the A-type granite field of the discrimination diagram (Fig. 4).

The primitive-mantle normalised spidergram for Cerro La Gloria pluton shows marked negative $\mathrm{Ba}, \mathrm{Nb}, \mathrm{Sr}, \mathrm{P}, \mathrm{Eu}$ and $\mathrm{Ti}$ anomalies and significant enrichment in $\mathrm{Rb}, \mathrm{Th}, \mathrm{U}$, and $\mathrm{Pb}$ (Fig. Sa). Rare earth element (REE) abundances of the granitoids are relatively high, varying from 226 to 444 ppm (Table 1). Their REE patterns are flat or slightly enriched in LREE with values of $\mathrm{La}_{N} / \mathrm{Yb}_{\mathrm{N}}$ from 2.6 to 20.3 and significant negative Eu-anomalies $\left(\mathrm{Eu}_{\mathrm{N}} / \mathrm{Eu}^{*}{ }_{\mathrm{N}}=0.03-0.34\right.$ ) (Fig. Sb). These patterns are similar to those reported for other A-type granites (e.g., Konopelko et al., 2007; Dahlquist et al., 2010). In contrast, the granite wall-rock samples display relative depleted patterns (except $\mathrm{Ba}, \mathrm{Sr}$, Eu, P and Ti) (Fig. 5a). The total REE contents of the Ordovician granitic samples are low (143-229 ppm), they have relatively flat REE patterns with $\mathrm{La}_{\mathrm{N}} / \mathrm{Yb}_{\mathrm{N}}=5.1-9.6$ and intermediate negative Eu-anomalies with $\mathrm{Eu}_{\mathrm{N}} / \mathrm{Eu}^{*}{ }_{\mathrm{N}}=0.59-0.60$ (Table 1 and Fig. 5 b).

The rhyolite dyke samples have a HSFE concentration range very similar to that of the Cerro La Gloria granitoids (Table 1); they plot in the primitive-mantle normalised spidergram with similar patterns, suggesting a common petrogenetic process (Fig. 5c). REE patterns are also similar (rhyolites have $\mathrm{Ia}_{\mathrm{N}} / \mathrm{Yb}_{\mathrm{N}}=7.4$ and 7.8 and $\mathrm{Eu}_{\mathrm{N}}$ / $\mathrm{Eu}^{*}{ }_{\mathrm{N}}=0.02$ ) (Fig. 5d), suggesting effective plagioclase crystallisation. REE total abundances are 347-357 ppm (Table 1). The primitive-mantle normalised spidergram for the less siliceous dykes shows similar pattems to the rhyolites, but with lower negative $\mathrm{Ba}, \mathrm{Sr}$ and $\mathrm{Ti}$ anomalies and significant enrichment in $\mathrm{Ia}, \mathrm{Ce}, \mathrm{Nd}, \mathrm{Zr}, \mathrm{Eu}$ and $\mathrm{P}$ (Fig. Sc). The trachyandesite and rachyte have extreme REE enrichment with total REE values of 478 and 683 ppm, respectively. The trachyandesite has $\mathrm{La}_{\mathrm{N}} /$ $\mathrm{Yb}_{\mathrm{N}}=9.2$ and lacks an Eu-anomaly $\left(\mathrm{Eu}_{\mathrm{N}} / \mathrm{Eu}^{*}{ }_{\mathrm{N}}=0.95\right)$ while the trachyte has IREE enrichment with $\mathrm{La}_{\mathrm{N}} / \mathrm{Yb}_{\mathrm{N}}=20.9$ and a slightly negative Eu-anomaly $\left(\mathrm{Eu}_{\mathrm{N}} / \mathrm{Eu}^{*}{ }_{\mathrm{N}}=0.76\right.$ ) (Fig. 5d). This is reasonably consistent with differentiation by crystal fractionation resulting eventually in the differentiated rhyolites. All the dyke samples plot in the field of A-type granites on the $\mathrm{Ce}+\mathrm{Nb}+\mathrm{Zr}+\mathrm{Y}$ vs. $10,000 * \mathrm{Ga} / \mathrm{Al}$ discrimination diagram (Fig. 4).

\section{3. $\mathrm{Nd}$ isotope composition}

The three analysed samples have roughly similar ${ }^{147} \mathrm{Sm} /{ }^{144} \mathrm{Nd}$ $(0.1071-0.1170)$ and ${ }^{143} \mathrm{Nd} /{ }^{144} \mathrm{Nd}(0.512158-0.512211)$ ratios (Table 3). Initial $\varepsilon N d t$ values calculated at a reference age of $349 \mathrm{Ma}$ (the U-Pb SHRIMP zircon crystallisation age - see Section 7) are close to zero $(-0.58$ to +0.46$)$ and $\mathrm{Nd}$ model ages calculated according to De Paolo et al. (1991) are 1.07 to $1.16 \mathrm{Ga}$, i.e., latest Mesoproterozoic.

\section{Zircon thermometry}

As the Cerro La Gloria samples are metaluminous to slightly peraluminous, the zircon geothermometer of Watson and Harrison (1983) can be used to estimate magmatic temperatures. The results of these calculations are given in Table 1 for $\mathrm{M}$ values between 0.9 and 1.7 (the calibration range for the geothermometer). The calculated temperatures give a value of $803 \pm 17^{\circ} \mathrm{C}$ (average for 6 samples) and a similar temperature is calculated for the rhyolite $\left(816^{\circ} \mathrm{C}\right.$, av. of 2 samples). The value for the granite should be interpreted as maximum due to the presence of inherited zircon (see next section). Temperatures reported in the literature for A-type granites are consistent with our data (e.g., Dahlquist et al., 2010); they are usually higher than those for calc-alkaline granitoids with similar $\mathrm{SiO}_{2}$ contents.

\section{Geochronology}

Zircons were separated from sample FAM-177 at the Department of Petrología y Geoquímica, Complutense University, Madrid, Spain, and analysed for U-Pb isotopic composition using SHRIMP RG at the 

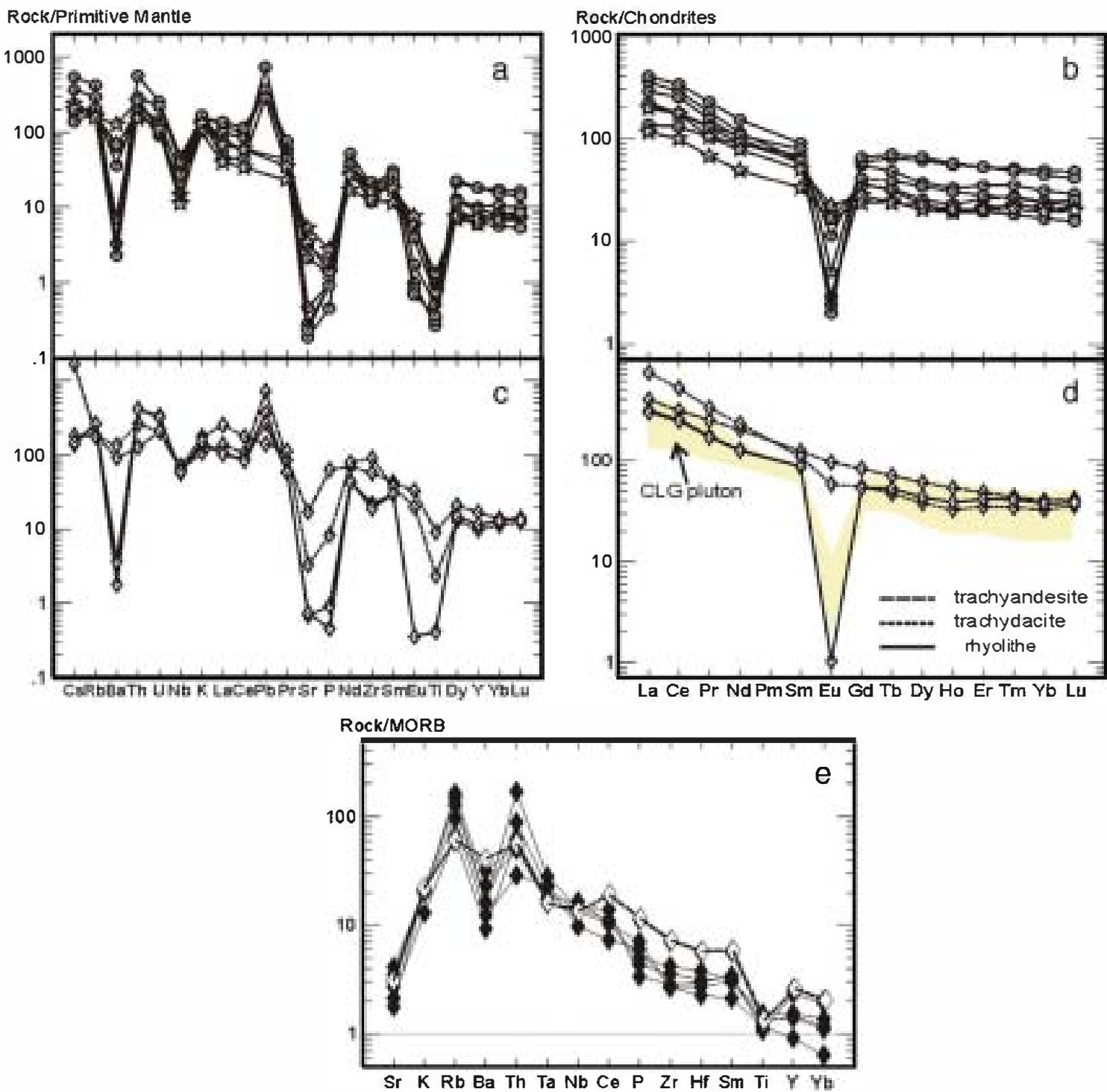

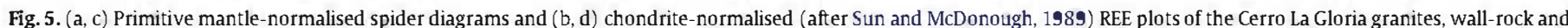

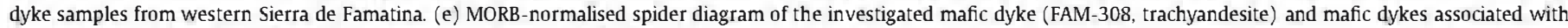
the A-type granitoids of the Sierras Pampeanas. Symbols are as in Fig. 3.

Australian National University, Canberra (Williams, 1998). Photographic and cathodo-luminescence images (Fig. 6a) show that they are mostly platy needles with moderately euhedral terminations, and with outer concentric zones surrounding complex inner cores, and occasionally with a thin outermost rim of luminescent (low-U) zircon. The igneous crystallisation of the granitoid is thought to be represented by the concentric zonation, best developed in the tips of long crystals, which were targeted for analysis. Twenty-one analyses were carried out (Table 4) and are plotted in a Tera-Wasserburg diagram (Fig. 6b). Following standard practise for young ages dated by SHRIMP, we calculated ${ }^{238} \mathrm{U} /{ }^{206} \mathrm{~Pb}$ ages after correcting for common $\mathrm{Pb}$ on the basis of the measured ${ }^{207} \mathrm{~Pb}$. Three analyses, one at $176 \mathrm{Ma}$ and two close to $300 \mathrm{Ma}$, appear to have suffered major $\mathrm{Pb}$-loss compared to the rest, whereas inheritance of more radiogenic $\mathrm{Pb}$ (associated with the presence of older zircon cores) may account for the two oldest ages of c. $360 \mathrm{Ma}$. The remaining 16 ages range beyond the limits of analytical uncertainty, from 327 to $352 \mathrm{Ma}$, but ignoring the four youngest, where Pb-loss may be significant, twelve give a well-defined mean of $349 \pm 3 \mathrm{Ma}(\mathrm{MSWD}=1.1)$. This age is taken as the best estimate of the crystallisation age, dating the emplacement of the CLG pluton as within the Tournaisian stage of the Carboniferous period, according to the 2008 IUGS stratigraphic chart.

Table 3

Sm-Nd data for the Cerro La Gloria pluton, Sierra de Famatina.

\begin{tabular}{|c|c|c|c|c|c|c|c|c|c|}
\hline & $\mathrm{SiO}_{2}$ & Age (Ma) & $\mathrm{Sm}$ & Nd & ${ }^{147} \mathrm{Sm} /{ }^{144} \mathrm{Nd}$ & $\left({ }^{143} \mathrm{Sm} /{ }^{144} \mathrm{Nd}\right)_{\text {today }}$ & $\left({ }^{147} \mathrm{Sm} /{ }^{144} \mathrm{Nd}\right)_{t}$ & $\varepsilon N d(t)$ & $\mathrm{T}_{\mathrm{DM}}{ }^{*}(\mathrm{Ga})$ \\
\hline FAM177 & 75.05 & 349 & 9.47 & 53.5 & 0.1071 & 0.512403 & 0.512158 & -0.58 & 1.16 \\
\hline FAM178 & 82.61 & 349 & 8.78 & 46.6 & 0.1140 & 0.512472 & 0.512211 & 0.46 & 1.07 \\
\hline FAM180 & 78.00 & 349 & 13.8 & 71.1 & 0.1170 & 0.512457 & 0.512189 & 0.03 & 1.11 \\
\hline
\end{tabular}

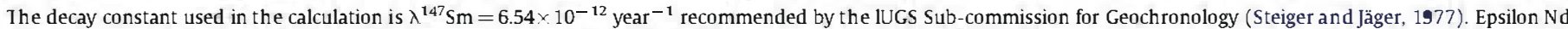

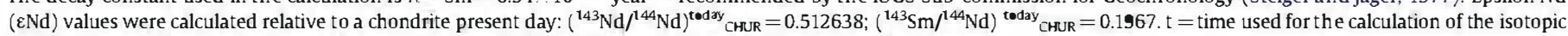
initial ratios. TDM $^{*}=$ calculated according to De Paolo et al. (1991). The age (349 Ma) is the calculated in this work. 

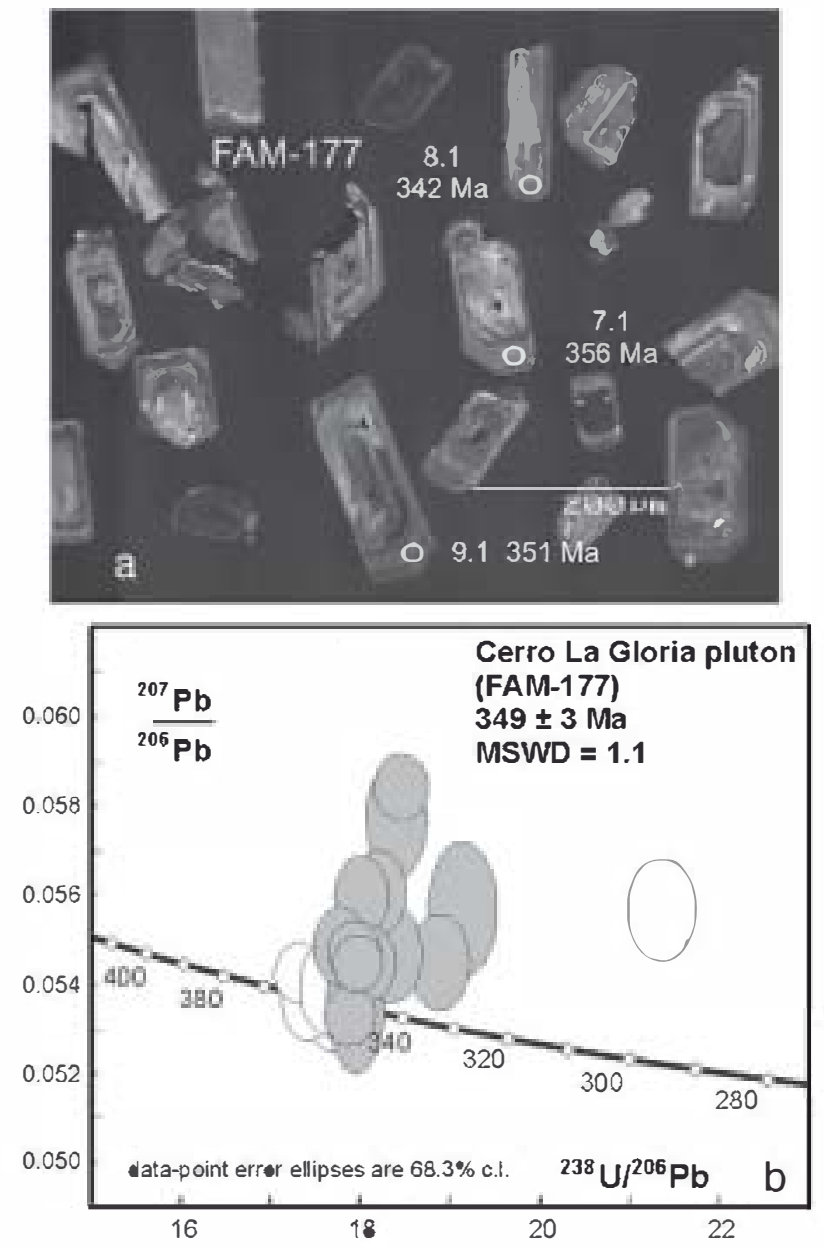

Fig. 6. (a) Cathodo-luminescence image of zircon grains showing areas analysed by SHRIMP, (b) Tera-Wasserburg diagram for the SHRIMP data for sample FAM-177. White ellipses are for points excluded from the age calculation.

\section{Petrogenetic discussion}

\subsection{Chemical composition of mafic minerals}

Due to corrosion of biotite it was possible to analyse only two grains from the pluton, and another from mafic microgranular enclaves. The fresh granite biotite grains are very iron-rich, with the ratio of $\mathrm{FeO}^{*}$ (total $\mathrm{FeO}$ ) to $\mathrm{MgO}$ above 8.9 and low $\mathrm{Al}_{2} \mathrm{O}_{3}$ content (about $12 \%$ ). In contrast, the enclave biotite shows decreasing in $\mathrm{FeO}^{*}$ with increasing $\mathrm{MgO}$ and $\mathrm{FeO}^{*} / \mathrm{MgO}$ of 3.2 , with a relatively high $\mathrm{Al}_{2} \mathrm{O}_{3}$ content of $12.81 \%$. Assuming that the composition of the granite biotite reflects the nature of the parental magma, these analyses correspond to anorogenic alkaline suites $\left(\mathrm{FeO}^{*} / \mathrm{MgO}>7.04\right.$, Abdel Rahman, 1994). Fluorine content is also distinctive: a biote grain in the enclave has $1.21 \%$, suggesting that the magma had a relatively high $\mathrm{HF} / \mathrm{H}_{2} \mathrm{O}$ ratio. In tum, similar chemical behaviour is observed in the ferro-edenite grains analysed for the pluton (FeO*/MgO about 9.6 and $\mathrm{F} 0.25 \%$ ) and enclave (FeO*/MgO about 4.4 and $\mathrm{F} 0.59 \%$ ).

\subsection{Source of the CLGP magma}

Chondrite-normalised REE plots and primitive-mantle normalised spider diagrams of studied igneous rocks (Fig. 5a-d) display some distinctive features:

(1) REE patterns tend to be flat to slightly LREE-enriched and have significant negative Eu anomalies for the more evolved igneous rocks (rhyolite and granitoid), suggesting plagioclase fractionation in the magma or retention in the source. Significant negative $\mathrm{Ba}$ and $\mathrm{Sr}$ anomalies in the spider diagrams reinforce this idea.

(2) Negative $P$ and Ti anomalies suggest that fractionation of apatite and $\mathrm{Fe}$-Ti oxides also played a role in both rock types.

(3) The relatively flat REE pattems of the studied rocks probably relate to low-pressure melting and differentiation (i.e., the absence of garnet in the source and/or residuum).

(4) The trachytic dyke (FAM-148 with $\mathrm{SiO}_{2} \sim 63 \%$ ) has relatively high values of $\mathrm{Ba}, \mathrm{Sr}, \mathrm{P}$, and Ti, but similar unfractionated REE

Table 4

Summary of SHRIMP U-Pb results for zircon from sample FAM-177. Cerro La Gloria pluton.

\begin{tabular}{|c|c|c|c|c|c|c|c|c|c|c|c|c|c|}
\hline \multirow{2}{*}{$\begin{array}{l}\text { Grain. } \\
\text { spot }\end{array}$} & \multirow{2}{*}{$\begin{array}{l}\mathrm{U} \\
\text { (ppm) }\end{array}$} & \multirow{2}{*}{$\begin{array}{l}\text { Th } \\
\text { (ppm) }\end{array}$} & \multirow{2}{*}{$\begin{array}{l}\text { Th/ } \\
\mathrm{U}\end{array}$} & \multirow{2}{*}{$\begin{array}{l}{ }^{2 \bullet} \mathrm{Pb}^{*} \\
(\mathrm{ppm})\end{array}$} & \multirow[t]{2}{*}{ Fow $x$} & \multicolumn{4}{|l|}{ Total } & \multicolumn{2}{|l|}{ Radiogenic } & \multicolumn{2}{|l|}{ Age (Ma) } \\
\hline & & & & & & 10upontros & \pm & ${ }^{200} \mathrm{~Pb}_{2}{ }^{206} \mathrm{~Pb}$ & \pm & 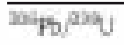 & \pm & ${ }^{2} \mathrm{P}_{\mathrm{y}} \mathrm{p}^{204} \mathrm{U}$ & \pm \\
\hline 1.1 & 702 & 396 & 0.56 & 34.0 & 0.16 & 17.7628 & 0.1987 & 0.0549 & 0.0006 & 0.0562 & 0.0006 & 352.5 & 3.9 \\
\hline 2.1 & 1183 & 715 & 0.60 & 58.7 & 0.06 & 17.3157 & 0.1857 & 0.0543 & 0.0004 & 0.0577 & 0.0006 & 361.7 & 3.8 \\
\hline 3.1 & 739 & 411 & 0.56 & 36.1 & 3.07 & 17.5748 & 0.2022 & 0.0782 & 0.0023 & 0.0552 & 0.0007 & 346.1 & 4.0 \\
\hline 4.1 & 1062 & 537 & 0.51 & 50.9 & 0.15 & 17.9216 & 0.1936 & 0.0547 & 0.0005 & 0.0557 & 0.0006 & 349.5 & 3.7 \\
\hline 5.1 & 672 & 307 & 0.46 & 32.1 & 0.31 & 17.9994 & 0.2017 & 0.0560 & 0.0006 & 0.0554 & 0.0006 & 347.5 & 3.8 \\
\hline 6.1 & 588 & 291 & 0.49 & 29.0 & $<0.01$ & 17.4052 & 0.1983 & 0.0537 & 0.0006 & 0.0575 & 0.0007 & 360.1 & 4.0 \\
\hline 7.1 & 477 & 284 & 0.59 & 23.3 & 0.04 & 17.6230 & 0.2072 & 0.0539 & 0.0007 & 0.0567 & 0.0007 & 355.7 & 4.1 \\
\hline 8.1 & 494 & 341 & 0.69 & 23.2 & 0.17 & 18.3414 & 0.2153 & 0.0547 & 0.0007 & 0.0544 & 0.0006 & 341.6 & 4.0 \\
\hline 9.1 & 1144 & 743 & 0.65 & 55.0 & $<0.01$ & 17.8668 & 0.1918 & 0.0533 & 0.0004 & 0.0560 & 0.0006 & 351.2 & 3.7 \\
\hline 10 & 1128 & 756 & 0.67 & 52.5 & 0.65 & 18.4484 & 0.1991 & 0.0584 & 0.0005 & 0.0539 & 0.0006 & 338.1 & 3.6 \\
\hline 11 & 1402 & 1716 & 1.22 & 67.1 & 0.13 & 17.9574 & 0.1911 & 0.0545 & 0.0004 & 0.0556 & 0.0006 & 348.9 & 3.7 \\
\hline 12 & 467 & 243 & 0.52 & 21.8 & 0.55 & 18.3953 & 0.2216 & 0.0577 & 0.0009 & 0.0541 & 0.0007 & 339.4 & 4.0 \\
\hline 12 & 251 & 163 & 0.65 & 11.3 & 0.34 & 19.1345 & 0.2529 & 0.0557 & 0.0010 & 0.0521 & 0.0007 & 327.3 & 4.3 \\
\hline 13 & 653 & 252 & 0.39 & 16.0 & 2.46 & 35.1645 & 0.4258 & 0.0692 & 0.000 & 0.0277 & 0.0003 & 176.4 & 2.1 \\
\hline 14 & 865 & 609 & 0.70 & 41.1 & 0.13 & 18.0786 & 0.1990 & 0.0545 & 0.0006 & 0.0552 & 0.0006 & 346.6 & 3.8 \\
\hline 15 & 634 & 361 & 0.57 & 27.0 & 1.52 & 20.2133 & 0.2314 & 0.0647 & 0.0007 & 0.0487 & 0.0006 & 306.7 & 3.5 \\
\hline 16 & 388 & 197 & 0.51 & 18.6 & 0.02 & 17.9434 & 0.2191 & 0.0536 & 0.0011 & 0.0557 & 0.0007 & 349.5 & 4.2 \\
\hline 17 & 492 & 238 & 0.48 & 19.8 & 0.43 & 21.3682 & 0.2525 & 0.0557 & 0.0008 & 0.0466 & 0.0006 & 293.6 & 3.4 \\
\hline 18 & 644 & 415 & 0.64 & 30.4 & 0.33 & 18.1825 & 0.2053 & 0.0560 & 0.0006 & 0.0548 & 0.0006 & 344.0 & 3.8 \\
\hline 19 & 527 & 302 & 0.57 & 24.0 & 0.18 & 18.8811 & 0.2208 & 0.0545 & 0.0007 & 0.0529 & 0.0006 & 332.1 & 3.8 \\
\hline 20 & 491 & 293 & 0.60 & 23.8 & $<0.01$ & 17.6847 & 0.2073 & 0.0535 & 0.0007 & 0.0566 & 0.0007 & 354.6 & 4.1 \\
\hline
\end{tabular}

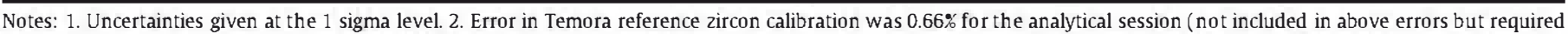

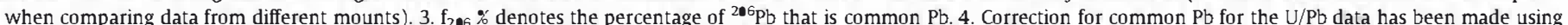

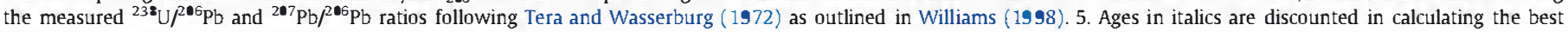
weighted mean age of $348.9 \pm 3.2 \mathrm{Ma}$. 

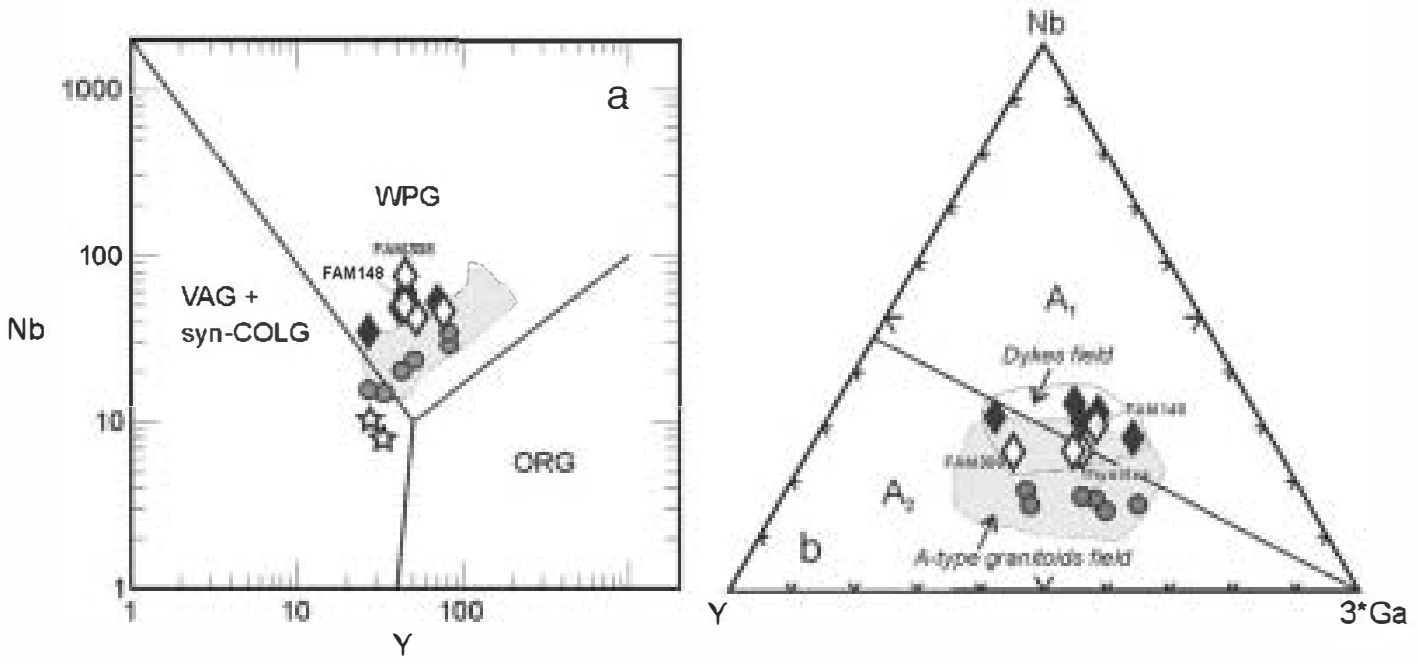

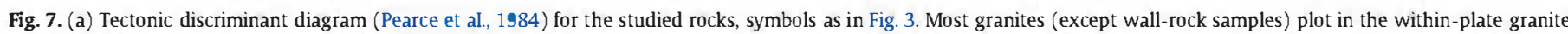
field. (b) Triangular Y-Nb-3 $\times$ Ga diagram of Eby (1992) used to distinguish between different source rocks for A-type magmas (A1 mantle-derived and A2 crust-derived).

patterns with a very slight negative Eu anomaly, compared to the evolved dykes (FAM-151 and FAM-155 with $\mathrm{SiO}_{2} \sim 77 \%$ ). This coincides with appreciable presence of feldspar and oxide phenocrysts in the trachyte, suggesting that all the dykes are related by a common petrogenetic process.

In the tectonic discriminant diagram of Pearce et al. (1984) the studied Carboniferous samples mainly fall in the field of within-plate granite (WPG, Fig. 7a), whereas the Ordovician wall-rock samples plot as volcanic arc and syn-collisional granitoids. Two groups of A-type igneous rocks have been recognised in the literature: those derived from a mantle source $\left(A_{1}\right)$ and those derived from melting of continental crust with or without a mantle input $\left(A_{2}\right)$ (Eby, 1992). The Cerro La Gloria samples fit into the second group $\left(A_{2}\right)$, while the all dykes (our dyke samples and those associated with the Carboniferous A-type granitoids, see Table 2) fall on the limit of $A_{1}$ and $A_{2}$ fields (Fig. 7b).

The $\varepsilon N d t$ values close to zero (Table 3 ) point to a minimal contribution from evolved crustal material. Dahlquist et al. (2010)

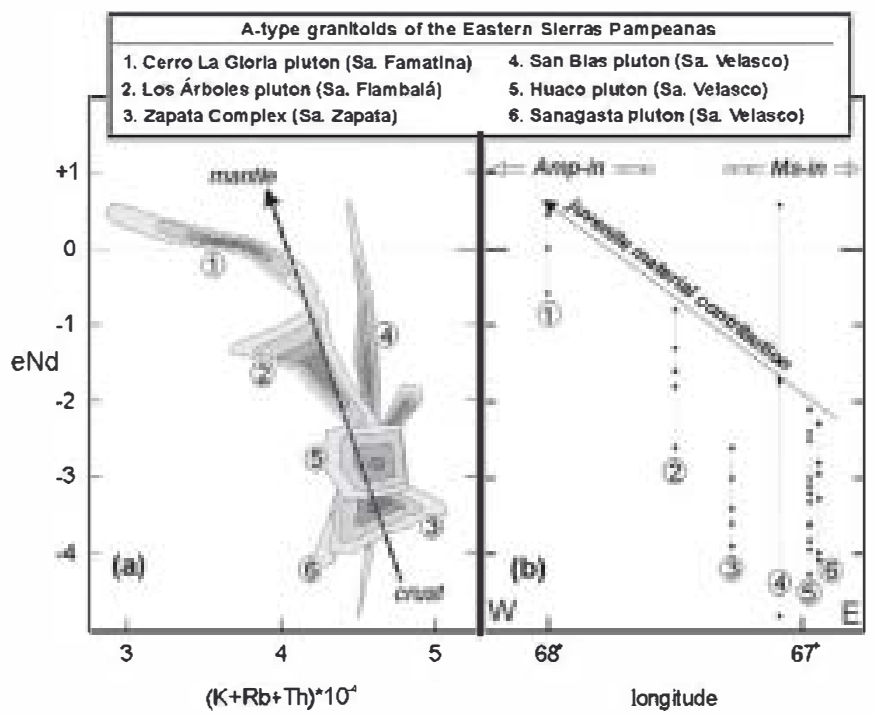

Fig. 8. Plots of $\varepsilon N d t$ vs. (a) $(K+R b+T h) \times 10^{-4}$ and (b) longitude. Data are for granitic rocks from the Cerro La Gloria pluton (this work) and the TIPA shear zone (Grosse et aL, 2009 and Dahlquist et aL, 2010). The grey fields contain the studied samples. The dark grey region represents the average for each pluton. proposed that the Carboniferous A-type granites emplaced in the TIPA shear zone represent variable mixtures of asthenospheric mantle and continental crust. Fig. 8a shows that the Cerro La Gloria samples have the least crustal character of these granites as proven by the most positive $\varepsilon N d t$ values and lowest contents of incompatible elements ( $\mathrm{K}, \mathrm{Rb}$ and $\mathrm{Th}$ ). This eastward (inland?) increase in $\varepsilon \mathrm{Ndt}$ values is accompanied by the disappearance of amphibole and the appearance of primary muscovite in the granites (Fig. 8b), as well as the trend to S-type plutons with alkaline tendency (e.g., La Costa and Sauce Guacho plutons, Table 5). Thus at the longitude of Sierra de Famatina (mainly) and Sierra de Fiambalá magma genesis involved a higher contribution of juvenile material of mantle character than to the east (i.e., Sierra de Zapata and Sierra de Velasco). The essential role of juvenile material, ultimately of asthenospheric origin, in the production of Carboniferous granites of the Eastern Sierras Pampeanas has been emphasised by Dahlquist et al. (2010). This does not necessarily require mantle melting to generate the parental magmas and, given the preponderance of siliceous granitoids, an intermediate stage of melting of juvenile mafic material, perhaps underplated at the base of the crust (and possibly formed much earlier) seems more likely.

\subsection{Mafic dykes related to A-type granitoids}

A common characteristic of the A-type plutons from the study region of the Eastern Sierras Pampeanas is their intrusion by mid-alkaline mafic dykes (Morello and Rubinstein, 2000; Grosse et al., 2009; Dahlquist et al., 2010 and this work). One trachyandesite sample (FAM-308) was analysed as part of this work while data for even more mafic samples were taken from previous work (Table 2). Even without age determinations for the dykes, field evidence (Fig. 9) suggests a coeval to late emplacement; e.g. (i) lobate contact with the Carboniferous granitoids, (ii) transfer of $\mathrm{K}$-feldspar phenocrysts from the granite to the dykes and (iii) some disaggregation of dykes within the granitoids or vice versa (Barbarin and Didier, 1992).

There is considerable geochemical evidence that alkaline dykes such as these may have been generated from an N-MORB (Normal Mid-Ocean Ridge Basalt) source enriched in lithophile mobile elements (e.g., Pearce and Peate, 1995). Fig. Se shows how the investigated dykes of the sierras of Famatina, Fiambalá and Velasco (all with $<58$ wt.\% $\mathrm{SiO}_{2}$ and associated with A-type granitoids, Table 2) have similar contents of Ti and HREE (i.e., immobile elements) but enrichment in $\mathrm{K}, \mathrm{Rb}, \mathrm{Cs}$, $\mathrm{Th}, \mathrm{Pb}$ and $\mathrm{Ba}, \mathrm{P}, \mathrm{Pb}$ and LREE ( $\mathrm{La}$ and $\mathrm{Ce}$ ). However, the relatively low abundances of compatible trace elements 
Table 5

Carboniferous igneous rocks of the western margin of Gondwana between $71^{\circ} 30^{\prime}$ and $67^{\circ} 00^{\prime} \mathrm{W}$.

\begin{tabular}{|c|c|c|c|c|c|}
\hline $\begin{array}{l}\text { Iongitude } \\
\text { location }\end{array}$ & Name & Lithology & Age $(\mathrm{Ma})^{\mathrm{a}}$ & $\begin{array}{l}\text { S-I-A-M } \\
\text { classification }\end{array}$ & $\begin{array}{l}\text { Isotopic signature } \varepsilon_{\mathrm{Na}} / \\
\mathrm{T}_{\mathrm{OM}}\end{array}$ \\
\hline $71^{\bullet} 30^{\prime} \mathrm{W} \mathrm{CC}$ & $\begin{array}{l}\text { Santo Domingo Complex } \\
\text { (Hervé et al., 1988; Parada et al., 1999) }\end{array}$ & Bt-Hbl tonalite-granodiorite & $308(\mathrm{Rb} / \mathrm{Sr}$ isochron $)$ & I-type & -1.7 to $-4.2 / 0.9$ to 1.5 \\
\hline $70^{\circ} 00 \mathrm{~W} \mathrm{CC}$ & Caleta Ioa (Lucassen et aI., 1999) & Bt granite & $310 \pm 10(\mathrm{~K} / \mathrm{Ar} \mathrm{Bt})$ & I- and S-type? & $-5 / 1.87$ \\
\hline $69^{\circ} 45^{\prime} \mathrm{W}$ PC & Sierra del Tigre (Sessarego et al., 1990) & Rhyolite to basalt dykes & $337 \pm 10(\mathrm{Rb} / \mathrm{Sr}$ isochron $)$ & 7 & 7 \\
\hline $69^{\circ} 30^{\prime} \mathrm{W} \mathrm{FC}$ & $\begin{array}{l}\text { Cerro Punta Blanca } \\
\text { (Caminos, 1979b; Gregori et al., 1996) }\end{array}$ & Granodiorite & $337 \pm 15(\mathrm{~K} / \mathrm{Ar} \mathrm{Bt})$ & I-type & 7 \\
\hline $69^{\circ} 30^{\prime} \mathrm{W}$ FC & $\begin{array}{l}\text { Cerro Carrizalito } \\
\text { (Dessanti and Caminos, 1967) }\end{array}$ & Bt tonalite-granodiorite & $341 \pm 17(\mathrm{~K} / \mathrm{Ar} \mathrm{Bt})$ & I-type & 7 \\
\hline $69^{\circ} 10^{\prime}$ W FC & Tabaquito (Llambias and Sato, 1995) & Bt-Hbl granodiorite & $\begin{array}{l}326-329(\mathrm{~K} / \mathrm{Ar} \text { whole } \\
\text { rock-Bt) }\end{array}$ & I-type & 7 \\
\hline $69^{\circ} 00^{\prime} \mathrm{W}$ PC & $\begin{array}{l}\text { Sa. Moreno (north) } \\
\text { (Lucassen et aI., 1999) }\end{array}$ & $\begin{array}{l}\text { Bt-Hbl tonalite, granodiorite and } \\
\text { granite }\end{array}$ & $\begin{array}{l}332 \pm 6 \text { to } 301 \pm 8 \\
(\mathrm{~K} / \mathrm{Ar} \mathrm{Bt})\end{array}$ & I- and S-type & $-5 / 1.71$ \\
\hline $68^{\circ} 45^{\prime}$ W FC & Las Tunas (Caminos, 1972) & Granite & $324 \pm 6(\mathrm{~K} / \mathrm{Ar} \mathrm{Bt})$ & I-type? & 7 \\
\hline $68^{\circ} 45^{\prime}$ W WSP & $\begin{array}{l}\text { Guandacolinos. Sa. de Umango } \\
\text { (Varela et al., 1996, 2004) }\end{array}$ & Granodiorite and granite & $314 \pm 14\left({ }^{2 \cdot 6} \mathrm{~Pb} /{ }^{3} \mathrm{U} Z \mathrm{rn}\right)$ & I-type & $+1.7 .+0.6 / 0.97 .1 .06$ \\
\hline $68^{\circ} 43^{\prime}$ W WSP & $\begin{array}{l}\text { Co. Veladero. Sa. de Umango } \\
\text { (Cingolani et al., 1993) }\end{array}$ & $\begin{array}{l}\text { Monzonite. monzodiorite, syenite } \\
\text { and granite }\end{array}$ & $311 \pm 15(\mathrm{Rb} / \mathrm{Sr}$ isochron $)$ & $\begin{array}{l}\text { I-type/alkaline } \\
\text { tendency }\end{array}$ & $-0.8 / 1.15$ \\
\hline $68^{\circ} 40^{\prime} \mathrm{PC}$ & $\begin{array}{l}\text { Punta del Agua, Rio Blanco } \\
\text { (Remesal et al., 2004) }\end{array}$ & Rhyolite to basalt & Carboniferous $^{\mathrm{b}}$ & I-type & $t$ \\
\hline $68^{\circ} 30^{\prime} \mathrm{W}$ PC & Potrerillos, Jagüe (Frigerio et al., 2010) & Tonalite to granite & $350 \pm 7\left({ }^{2 \bullet 6} \mathrm{~Pb} /{ }^{238} \mathrm{U} \mathrm{Zrn}\right)$ & $\begin{array}{l}\text { I-type/alkaline } \\
\text { tendency }\end{array}$ & $?$ \\
\hline $68^{*} 10^{\prime}$ W ESP & $\begin{array}{l}\text { Sierra del Toro Negro and S Puna } \\
\text { (Martina et al., 2011) }\end{array}$ & Rhyolite & $\begin{array}{l}342-348 \text { (U-Pb } 2 \mathrm{rn} \\
\text { SHRIMP) }\end{array}$ & A-type & $-0.4,-2.9 / 1.09,1.10$ \\
\hline $68^{\circ} 00^{\prime}$ W ESP & $\begin{array}{l}\text { Cerro La Gloria pluton. Sa. de Famatina } \\
\text { (this work) }\end{array}$ & Bt-Amp syenogranite & $\begin{array}{l}349 \pm 3(\mathrm{U}-\mathrm{PbZrn} \\
\text { SHRIMP) }\end{array}$ & A-type & $\begin{array}{l}+0.46 \text { to }-0.58 / 1.07 \text { to } \\
1.16\end{array}$ \\
\hline $67^{\bullet} 31^{\prime}$ W ESP & $\begin{array}{l}\text { Ios Árboles, Sa. de Fiambalá } \\
\text { (Grissom et al., 1998) }\end{array}$ & $\mathrm{Bt} \pm$ Amp syenogranite & $335-350\left({ }^{2} \mathrm{~Pb} /{ }^{23} \mathrm{U} \mathrm{Zrn}\right)$ & A-type & $\begin{array}{l}-0.8 \text { to }-2.6 / 0.96 \text { to } \\
1.30\end{array}$ \\
\hline $67^{\circ} 17^{\prime}$ W ESP & $\begin{array}{l}\text { Zapata Complex. Sa. de Zapata } \\
\text { (McBride et al., 1976) }\end{array}$ & Granite to syenogranite & $316-323(\mathrm{~K} / \mathrm{Ar} \mathrm{Bt})$ & A-type & $\begin{array}{l}-2.6 \text { to }-3.9 / 1.19 \text { to } \\
1.72\end{array}$ \\
\hline $67^{\circ} 06^{\prime}$ W ESP & $\begin{array}{l}\text { San Blas pluton Sa. de Velasco } \\
\text { (Dahlquist et al., 2006, 2010) }\end{array}$ & Granodiorite to syenogranite & $\begin{array}{l}340 \pm 3(\mathrm{U}-\mathrm{Pb} Z \mathrm{rn} \\
\text { SHRIMP) }\end{array}$ & A-type & $\begin{array}{l}+0.6 \text { to }-4.8 / 1.04 \text { to } \\
1.38\end{array}$ \\
\hline $67^{\circ} 00^{\prime}$ W ESP & $\begin{array}{l}\text { Asha pluton Sa. de Velasco } \\
\text { (Báez et al., 2004) }\end{array}$ & Granite to syenogranite & $344 \pm 1$ (U-Pb Mon) & A-type & 7 \\
\hline $67^{\circ} 00^{\prime} \mathrm{W}$ ESP & $\begin{array}{l}\text { La Costa pluton, Sa. de Velasco } \\
\text { (Alasino et al., 2010) }\end{array}$ & $\begin{array}{l}\text { Granodiorite to alkali-feldspar } \\
\text { granite }\end{array}$ & 340 to $350 \mathrm{Ma}^{\mathrm{c}}$ & $\begin{array}{l}\text { S-type/alkaline } \\
\text { tendency }\end{array}$ & ? \\
\hline $67^{\circ} 00^{\prime}$ W ESP & $\begin{array}{l}\text { Huaco Complex. Sa. de Velasco } \\
\text { (Grosse et al., 2009) }\end{array}$ & Granite to syenogranite & $350-358\left({ }^{206} \mathrm{~Pb} /{ }^{238} \mathrm{U}\right.$ Mon $)$ & A-type & $\begin{array}{l}-2.1 \text { to }-4.3 / 1.28 \text { to } \\
1.53\end{array}$ \\
\hline $67^{\bullet} 00^{\prime}$ W ESP & $\begin{array}{l}\text { Sanagasta pluton Sa. de Velasco } \\
\text { (Grosse et aI., 2009) }\end{array}$ & Granite to syenogranite & $353 \pm 1\left({ }^{2 \bullet 6} \mathrm{~Pb} /{ }^{238} \mathrm{U}\right.$ Mon $)$ & A-type & $\begin{array}{l}-2.3 \text { to }-4.1 / 1.22 \text { to } \\
1.43\end{array}$ \\
\hline $65^{\circ} 30^{\prime}$ W ESP & $\begin{array}{l}\text { Sauce Guacho pluton Sa. de Ancasti } \\
\text { (Kniiver, 1983) }\end{array}$ & Two-micas granite & $334 \pm 10(\mathrm{Rb} / \mathrm{Sr}$ isochron $)$ & $\begin{array}{l}\text { S-type/alkaline } \\
\text { tendency }\end{array}$ & $?$ \\
\hline
\end{tabular}

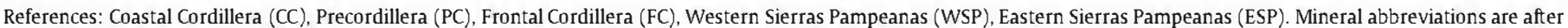
Kretz (1983).

a Ages determined by different analytical techniques as shown ages are considered to represent either crystallisation or cooling as treated in the text.

b Age based on stratigraphical relations and radiometric dating.

c Age inferred from the observation that the La Costa pluton cuts the Asha pluton (344 Ma) but not the San Blas pluton (340 Ma).

such as $\mathrm{Ni}(<183 \mathrm{ppm})$ and $\mathrm{Cr}(<311 \mathrm{ppm})$ (elements concentrated in olivine and pyroxene) show that the dykes do not represent primary magmas. In the $\mathrm{Nb} / \mathrm{Y}$ vs. $\mathrm{Zr} / \mathrm{TiO}_{2} * 10^{4}$ and $\mathrm{SiO}_{2}$ vs. $\left(\mathrm{Na}_{2} \mathrm{O}+\mathrm{K}_{2} \mathrm{O}\right)$ diagrams (Fig. 10a-b) they fall in the alkaline-basalt/alkalic fields, although with one anomalous sample (high $\mathrm{Zr}$ content) and some transition to subalkaline series (respectively). In the $\mathrm{Zr}-\mathrm{TiO}_{2}$ diagram (Fig. 10c) the dykes show within-plate affinities, but they overlap the $\mathrm{N}$-MORB field. Even more, in geochemical discrimination diagrams for potassic rocks (Müller et al., 1992), the mafic dykes tend to plot in the continental arc, rather than within-plate and post-collisional arc fields (Fig. 10d-e). All these features are compatible with the transitional basalt patterns (Pearce, 1982), corresponding to basalts in or adjacent to continental areas of initial stages of back-arc rifting (e.g., Shinjo et al., 1999; Farahat et al., 2004; Pearce and Stern, 2006; Yao-Hui et al., 2006). In fact, the studied basaltic dykes in the $\mathrm{Zr}$ vs. Ba diagram (Fig. 10f) are classified as back-arc basalt. Back-arc basin basalts were initially classified as intermediate between MORB and island-arc basalt (Fryer et al, 1981). They are generated by decompression melting of MORB (Klein and Langmuir, 1987), with a subduction component clearly involved (e.g., Müller et al., 1992) indicating modification of the mantle at convergent margins. A possible geodynamic origin will be developed in the next section.
8.4. Implications for the Carboniferous crustal evolution of the protoAndean margin

\subsubsection{Tectonic interpretation of A-type granitoids}

It is known that A-type magmas are formed in various extensional regimes: in continental back-arcs, in post-collisional extension and in within-plate settings (e.g., Eby, 1992; Whalen et al., 1996). Eby (1992) showed that the A1 group is restricted to anorogenic settings (hotspots, plumes and continental rift zones), but that the $A 2$ group rocks are associated with a wide variety of tectonic settings. As noted above, the Early Carboniferous granites of the Eastern Sierras Pampeanas belong to the $\mathrm{A} 2$ group, whereas the dykes are intermediate between the two types. A magmatic origin related to anorogenic setting (e.g., intra-continental rifting) does not seem to be applicable to these rocks. Shoshonite series volcanic rocks (similar to the studied A-type and associated dykes - see Fig. 13a) are usually attributed to a back-arc setting (Peccerillo and Taylor, 1976). Although we do not strictly apply this concept, recent numerical models of convergent margins (see Currie et al., 2007) show that the buoyant subducted sediments may detach from the subducting plate at $100 \mathrm{~km}$ depth and become attached to the retro-arc region, destabilising and thinning the lithosphere. Therefore, any input of fluid or melt from the 

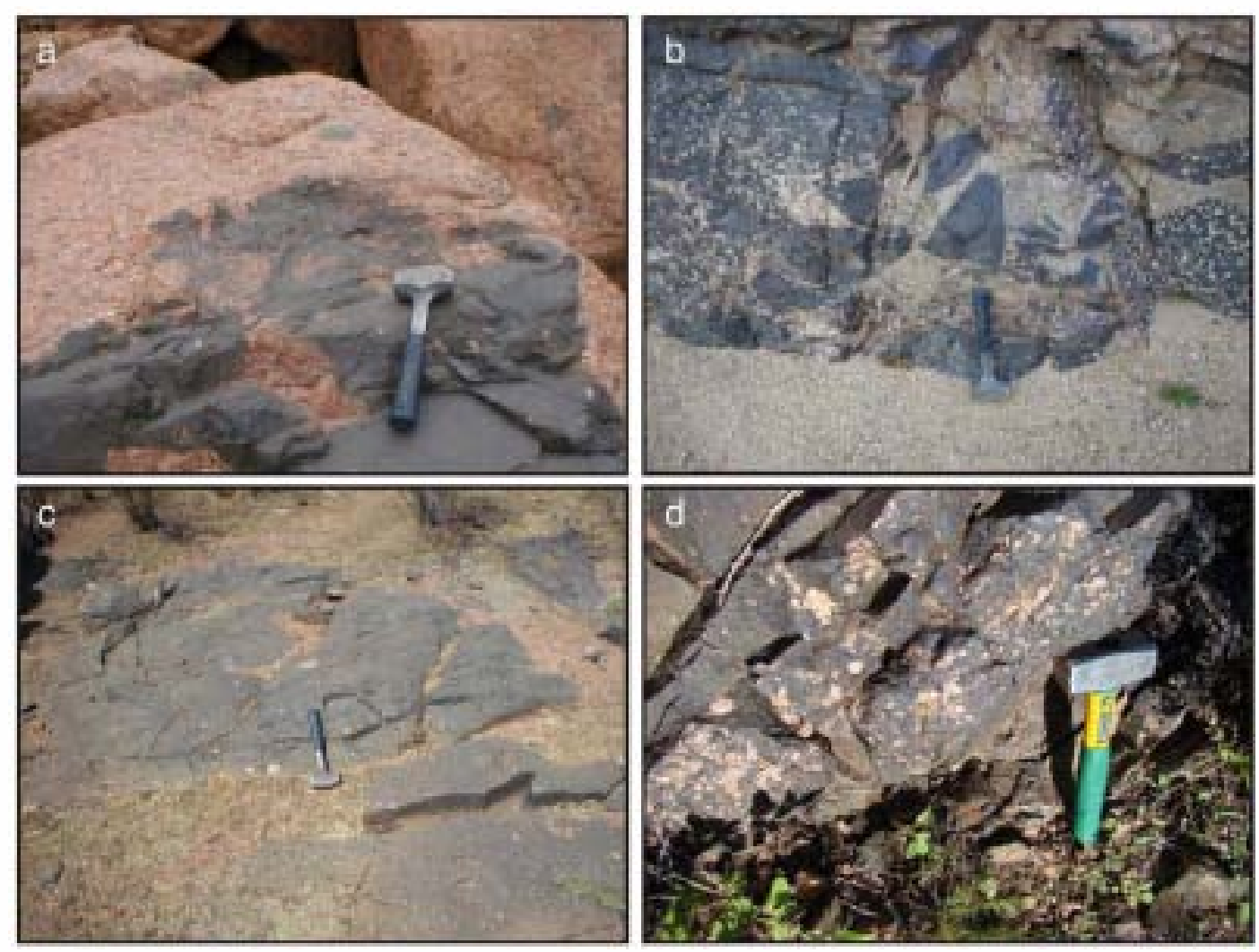

Fig. 9. (a) and (b) Mafic dykes intruding the Los Árboles pluton in the Sierra de Fiambalá. Lobate margins (a) and some disaggregation (b) show synchronism with pluton emplacement. Mafic dykes intruding the Huaco $(c)$ and San Blas (d) plutons, containing K-feldspar phenocrysts and/or granite fragments of the host.
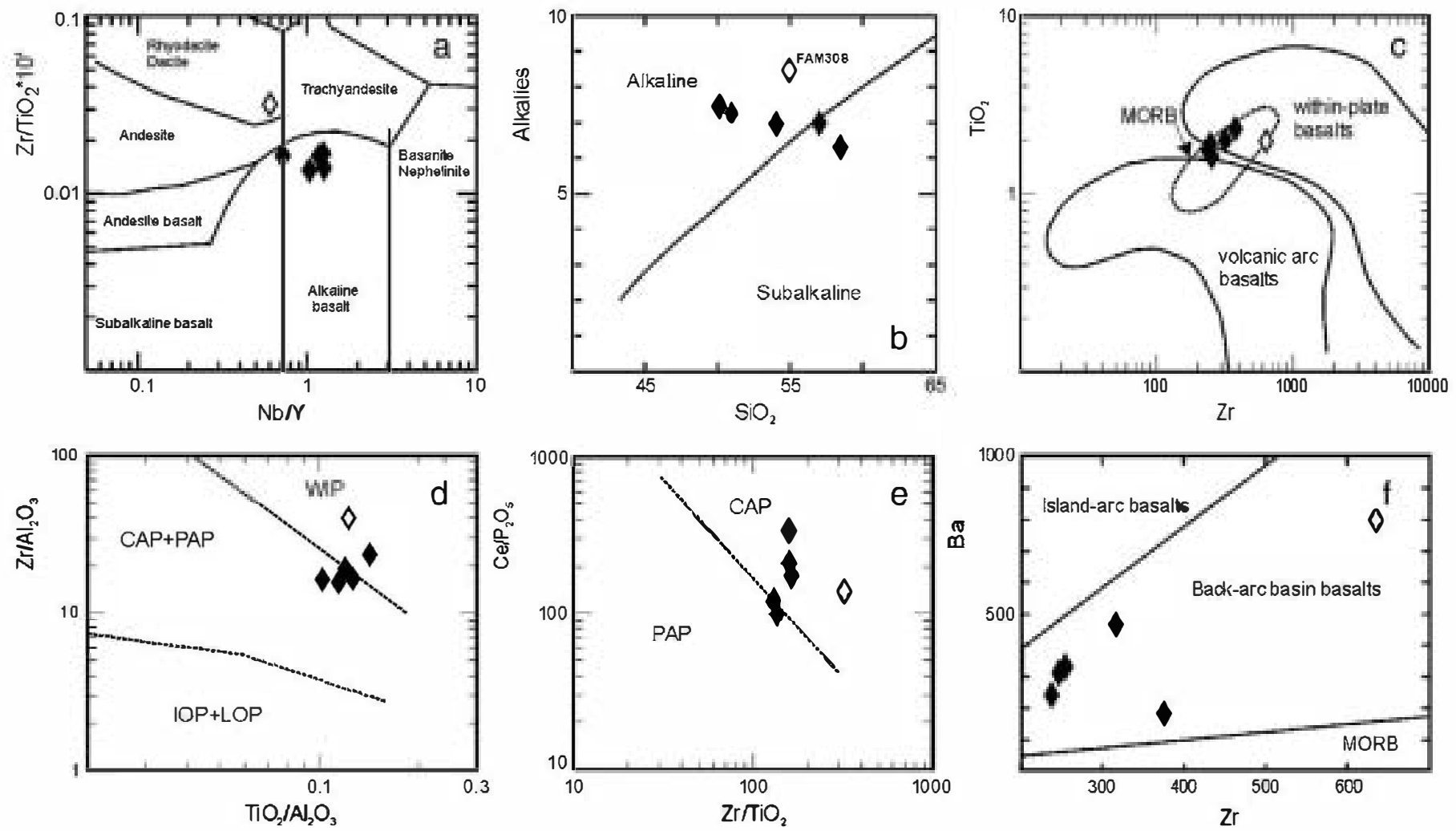

Fig. 10. Plots of (a) $\mathrm{Nb} / \mathrm{Yvs} . \mathrm{Zr} / \mathrm{IiO}_{2} * 10^{4}$ (Winchester and Floyd, 1977), (b) $\mathrm{SiO}_{2}$ vs. $\mathrm{Na}_{2} \mathrm{O}+\mathrm{K}_{2} \mathrm{O}$, (c) Zrvs. $\mathrm{TiO}_{2}\left(\mathrm{Pearce}, 1982\right.$ ), (d) $\mathrm{TiO}_{2} / \mathrm{Al}_{2} \mathrm{O}_{3}$ vs. $\mathrm{Zr} / \mathrm{Al}_{2} \mathrm{O}_{3}$ ( $\left(\mathrm{Miilleret}\right.$ al., 1992 ), (e) $2 \mathrm{r} / \mathrm{\Gamma iO} \mathrm{O}_{2}$ vs. $\mathrm{Ce} / \mathrm{P}_{2} \mathrm{O}_{5}$ (Müller et al., 1992) and (f) Zrvs. Ba (Saunders and Tarney, 1979). MORB, mid-ocean ridge basalt; WIP, within plate potassic rocks; CAP, continental arc potassic rocks; PAP, postcollisional arc potassic rocks; 1OP, initial oceanic arc potassic rocks; LOP, oceanic arc potassic rocks. Symbols are as in Fig. 3. 


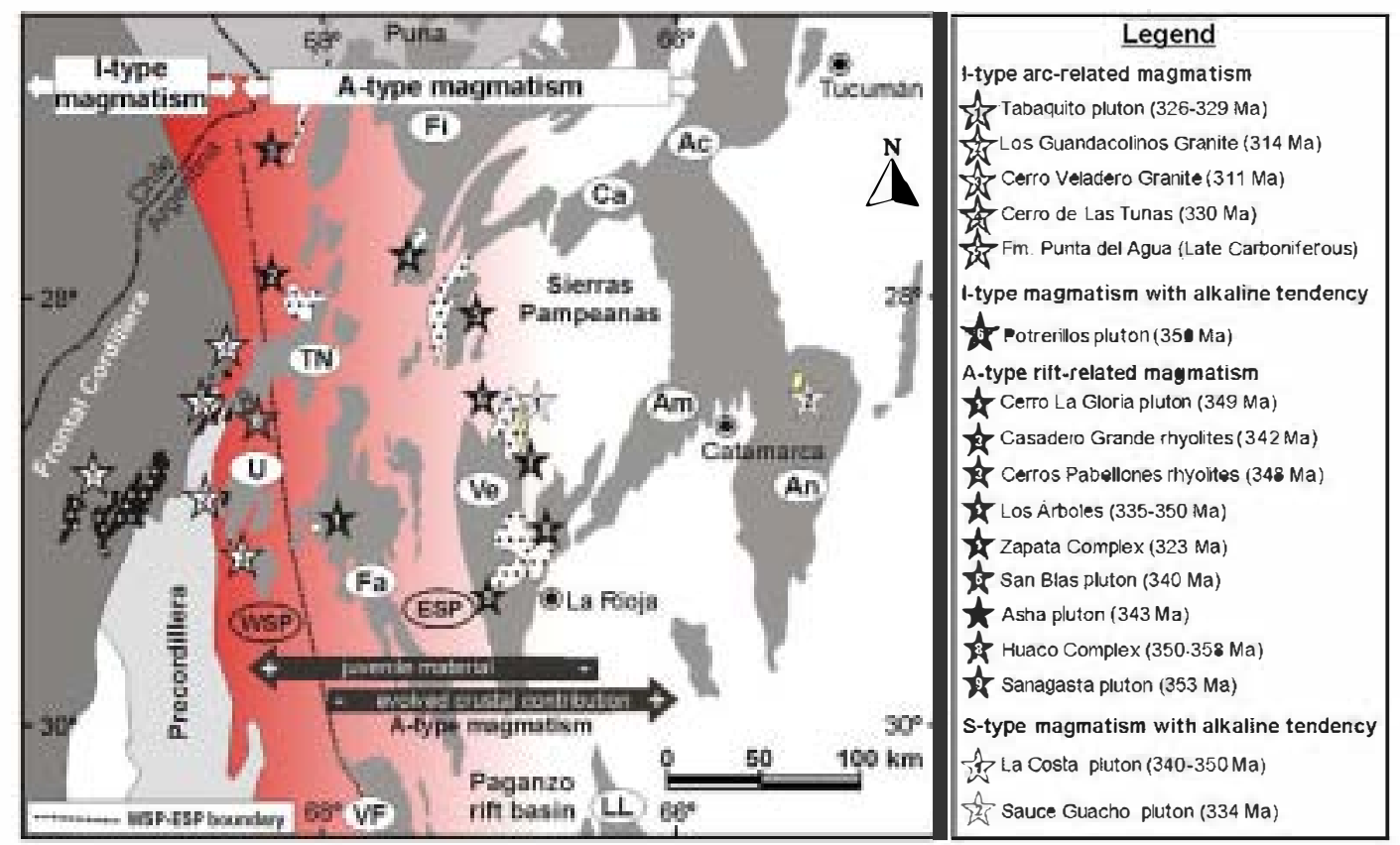

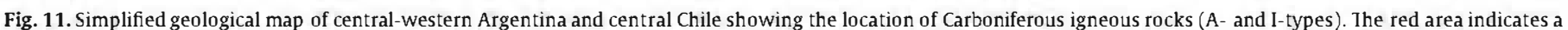

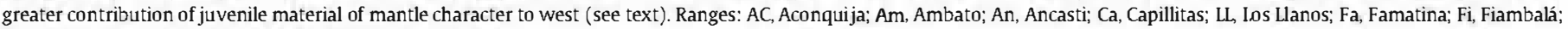
TN, Toro Negro; U, Umango; Ve, Velasco; VF, Valle Fértil.

subducting slab (e.g., rich in K, Rb, Th, Be, Li and B, Nelson, 1992; Johnson and Plank, 1999, among others) may has a strong impact on the mantle wedge and the magmas generated there (e.g., Pearce and Stern, 2006; Currie et al., 2007). In fact, most of these elements occur in anomalously high concentrations in the Early Carboniferous sub-to-mid-alkaline granitoids (e.g., Grosse et al., 2009; Dahlquist et al., 2010) and the occurrence of hydrothermal lithium-mica in a greisen hosted in Early Carboniferous granitoids at Sierra de Fiambalá,

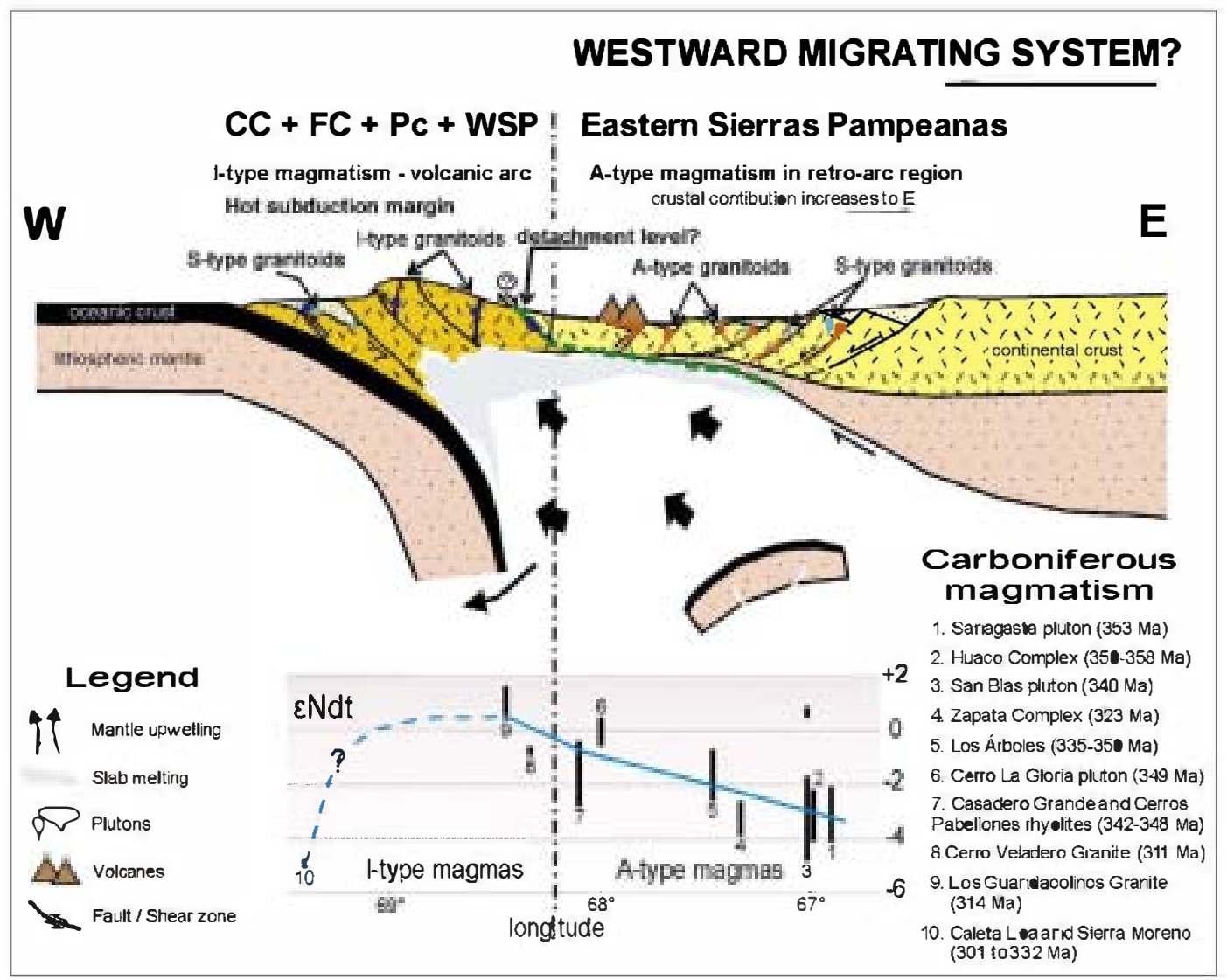

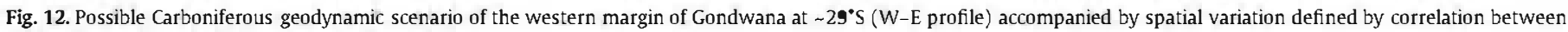
$\varepsilon N d t$ values and longitude for all granitoids at $-29^{\circ} \mathrm{S}$. 


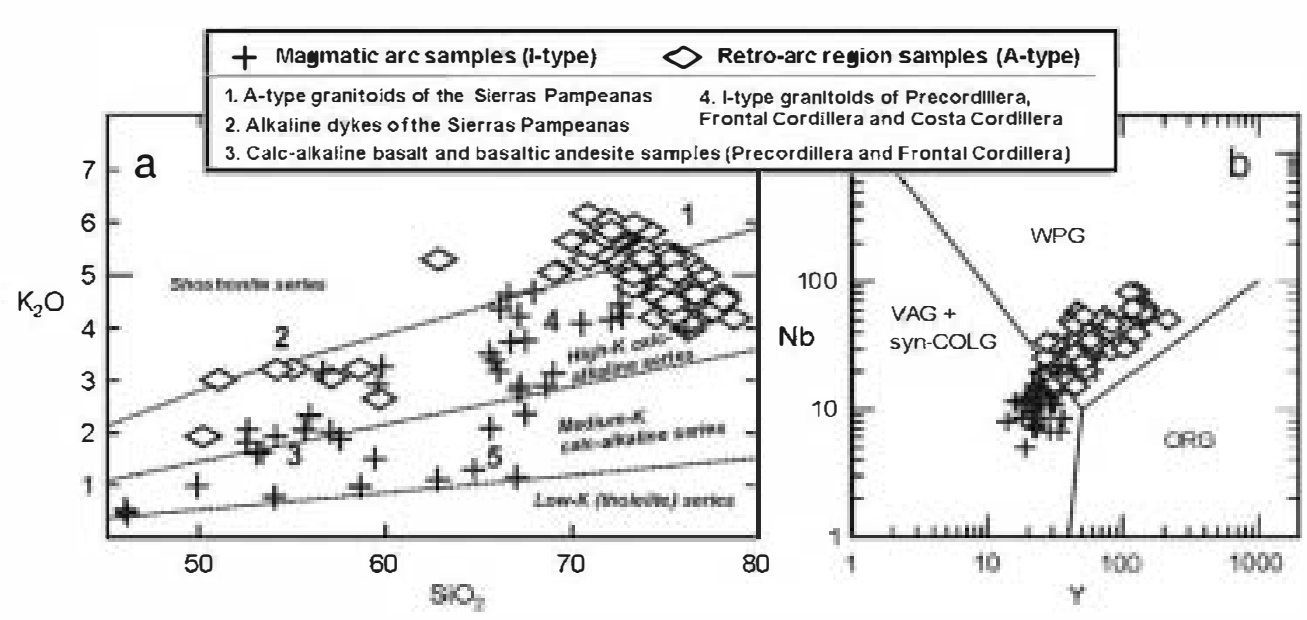

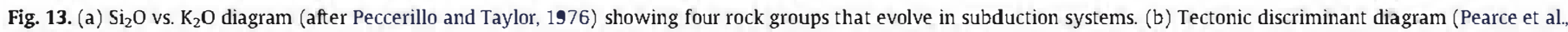

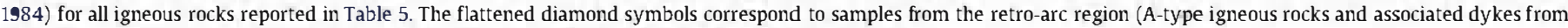
Table 2), whereas crosses correspond to samples of the magmatic arc rocks (I-type igneous) in Table 5 .

dated at $339 \pm 8 \mathrm{Ma}(\mathrm{K} / \mathrm{Ar}$ in mica, Avila et al., 2008) may also be significant in this regard. Thus, integrating all information for the studied A-type granitic rocks and associated dykes from the Eastern Sierras Pampeanas, a feasible scenario is one of extensional settings inboard from a subduction zone.

\subsubsection{Carboniferous granitoids}

Previous studies have reported Carboniferous I-type calc-alkaline magmatism from the western region of Argentina and Chile (i.e., $68^{\circ} 30^{\prime}$ to $71^{\circ} \mathrm{W}$ : the Western Sierras Pampeanas, Precordillera, Frontal Cordillera and Coastal Cordillera, see Table 5). The parent magmas are regarded as having formed above a N-S trendingvolcanic arc, resulting in dominantly intermediate compositions with biotite \pm homblende and with calc-alkaline signatures (e.g., Gregori et al., 1996). Their genesis is linked to an active convergent margin with eastward subduction of the oceanic plate in Carbonif erous times (Caminos, 1979b; Hervé et al., 1988; Llambias and Sato, 1995; Gregori et al., 1996; Lucassen et al, 1999; Parada et al., 1999; Remesal et al., 2004). However, some authors (e.g., Willner et al., 2011) have suggested for this region two different

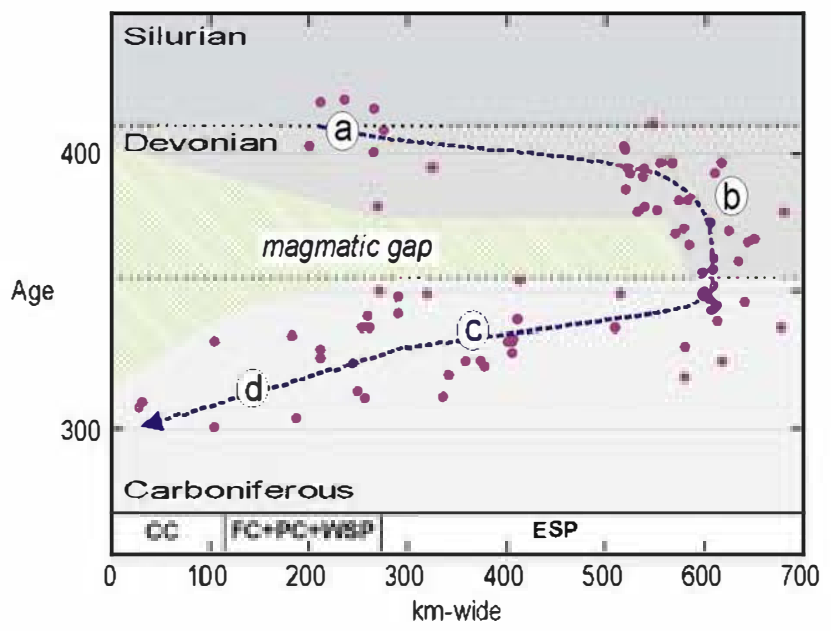

Fig. 14. Time-space plot of Late Palaeozoic magmatism on the western margin of Gondwana at $28^{\circ}-33^{\circ} \mathrm{S}$. For explanation of a, b, c and d, see text. The ordinate scale is estimated distance from the current subduction trench, as a reference measure only. CC, Coastal Cordillera; FC, Frontal Cordillera; PC, Preoordillera and SPP, Sierras Pampeanas. Data used in the figure are available in Supplementary data table. geotectonic relationships with two magmatic events during the Carbonif erous: (i) assumed post-collisional granitoids (ca. 337-348 Ma) in the Cordillera Frontal (see Fig. 10 in Willner et al., 2011) and (ii) volcanic arc I-type granitoids in the Coastal Cordillera (ca. $310 \mathrm{Ma}$ ) (Hervé et al., 1988; Lucassen et al., 1999; Parada et al., 1999). Unfortunately, there are no robust ages for the granitoids of Cordillera Frontal. K-Ar determinations, mostly on biotite (see summary in Table 5), provide only a minimum ages ranging from -320 to 341 Ma for these bodies, apparently younger than relatively high-P regional metamorphism in the Cordillera Frontal dated by Willner et al. (2011) at ca. $390 \mathrm{Ma}$, with exhumation through the muscovite closure temperature for Ar at ca. $350 \mathrm{Ma}$. They could thus represent a Iate-Devonian to Early Carboniferous postorogenic phase following Chilenia terrane collision, as argued by Willner et al. (2011). However, in the absence of other definitive evidence for this phase being related to terrane collision, we suggest exhumation (pull) of the Cordillera Frontal after collapse of the thickened continental wedge resulting from a Late Devonian flat-slab contractional (push) phase of the Pacific active margin evolution (see suggested petrogenetic model in next section). More robust age determinations and petrological, geochemical and isotope data are needed to resolve these alternative tectonic scenarios.

Regardless of these alternative geotectonic settings, general comparison of Carboniferous granites at $27^{\bullet}-30^{\bullet} \mathrm{S}$ reveals an evident compositional boundary (Table 5 and Fig. 11): Carbonif erous I-type granites crop out in the Western Sierras Pampeanas whereas Early Carboniferous A-type granites are restricted to the Eastern Sierras Pampeanas. In fact, some plutons located at $\sim 68^{\circ} 30^{\prime} \mathrm{W}$ (i.e., the approximate limit between these I- and A-type granitoids) show a transition to alkaline lineages and sub-circular forms (e.g., the Potrerillos and Cerro Veladero plutons, Table 5 and Fig. 11). Overall, we also note features such as (1) Nd model ages suggesting involvement of material derived from a relatively juvenile late Mesoproterozoic crust (a peak between 1.0 and $1.4 \mathrm{Ga}$ ); (2) smooth correlation between $\varepsilon \mathrm{Ndt}$ values and longitude indicates a continuously varying contribution of juvenile material to this orogenic cycle but also suggests a common process of magma generation for all the Carboniferous granites (Fig. 12); (3) in the $\mathrm{SiO}_{2}$ vs. $\mathrm{K}_{2} \mathrm{O}$ diagram most of the igneous rocks fall in the high-K calc-alkaline field, and even those from the Eastern Sierras Pampeanas (i.e., A-type granitoids and dykes, 1 and 2 in Fig. 13a, respectively) plot on the limit between shoshonite and high-K calc-alkaline series; and (4) the tectonic discriminant diagram of Pearce et al. (1984) (Fig. 13b) shows that the granitoids between $68^{\circ} 30^{\prime}$ and $71^{\circ} 30^{\prime} \mathrm{W}$ (Table 5) fall in the field of volcanic arc and syn-collisional granitoids, whereas those located between 
$67^{\circ} 00^{\prime}$ and $68^{\circ} 15^{\prime} \mathrm{W}$ (i.e., in the Eastern Sierras Pampeanas) correspond to within-plate granitoids.

Gregori et al. (1996) have suggested that Carboniferous I-type granites of the Cordillera Frontal were generated in an active margin with dominant crustal extension, whereas previous data (Dahlquist et al., 2010; Martina et al., 2011) and those presented here suggest that Carboniferous A-type of the Eastern Sierras Pampeanas were generated in a retro-arc setting. Additionally, we have demons rated systematic geochemical and isotopic variations in Early Carboniferous A-type granitoids from the Eastem Sierras Pampeanas at $\sim 27^{\circ}-30^{\circ} \mathrm{S}, 67-68^{\circ} 15^{\prime} \mathrm{W}$ (Fig. 11), that suggest a progressive lithospheric thinning towards the West, leading to participation of more juvenile material in the magmas.

\section{Geodynamic implications for Late Palaeozoic time}

The current Andean margin of Gondwana can be considered an overall accretionary orogen, largely active since Neoproterozoic times (e.g., Vaughan and Pankhurst, 2008) with repeated alternation of lithosphere extension and contraction as well as occasional involvement of microcontinental blocks of disputable provenance (e.g. the Precordillera or Cuyania terrane, Chilenia microplate) (e.g., Ramos et al., 1986; Thomas and Astini, 2003; Casquet et al., 2008). This repeated tectonic switching can be related to shallowing and steepening of the subduction zones through time (e.g., Collins, 2002; Gorczyk et al., 2007; Li and Li, 2007; Lister and Forster, 2009). This would be consistent with our proposal that the A-type magmatism and associated dykes of the Eastern Sierras Pampeanas were generated in a retro-arc region linked to an active magmatic arc located to the west producing contemporaneous I-type granites. The boundary between I-type and A-type magmatism is coincident with that between the Western and Eastern Sierras Pampeanas basement blocks (Fig. 11), suggesting that a suture that may have had an important role in detachment of the lithosphere (Fig. 12). This could explain: (i) the greater contribution of juvenile material in the generation of the granites above this suture, such as the Cerro La Gloria pluton in the west of the Eastern Sierras Pampeanas and the Guandacolinos and Cerro Veladero plutons in the east of the Western Sierras Pampeanas (Fig. 12), (ii) the widespread development of silicic magmatism (ca. 342-348 Ma) with a juvenile input near this suture (Martina et al., 2011) (iii) the $>1000 \mathrm{~m}$ thick alluvial conglomerates of Early Carboniferous age that were deposited at $\sim 68^{\circ} 37^{\prime} \mathrm{W}$ (Astini et al., 2011). The appearance of evolved S-type granites farther east (such as La Costa and Sauce Guacho plutons, Table 5 and Fig. 12) could be related to Carboniferous decompression and/or thinning of the lithosphere (Nabelek and Liu, 2004; de los Hoyos et al., 2011) (Figs. 11 and 12). A tectonothermal scenario that may fit our rocks is a push-pull tectonic switching episode (e.g., Lister and Forster, 2009 and references therein), whereby Devonian horizontal lithospheric shortening is followed by Carboniferous lithosphere stretching resulting from accretion/roll-back in the Pacific margin. This would explain not only the development of broad intra-continental magmatism in the Sierras Pampeanas but also its temporal-spatial progressions. Fig. 14 shows this progression for the Silurian-to-Carboniferous igneous rocks of NW Argentina according to their distance from the current Andean trench. We can distinguish (a) a discrete Late Silurian to Early Devonian orogenic belt (e.g., Caminos et al., 1979; Varela et al., 1993; Cingolani et al., 2003) along the western margin of Gondwana (c. $420-390 \mathrm{Ma}$, Fig. 14a) and (b) a wide zone of Late Devonian intracontinental A-type magmatism located some $600 \mathrm{~km}$ to the east and emplaced in a relative short period (c. 390-365 Ma, Fig. 14b) together with W-directed compression at $\sim 380 \mathrm{Ma}$ (lira and Kirschbaum, 1990; Sims et al., 1998; López de Luchi et al., 2004; Rapela et al., 2008; Steenken et al., 2008). Here both magmatic events would be linked to an initial flat-slab subduction towards the east that caused Middle to Late Devonian lithospheric shorting, when metamorphism and deformation is recognised in the several parts of the Westem Gondwana margin (Ramos et al.,
1986; Basei et al., 1998; Varela et al., 2002; López and Gregori, 2004; Willner et al., 2011). Subsequent foundering and roll-back of the slab lead to the generation of Early Carboniferous A-type granitoids in the Eastern Sierras Pampeanas (c. 325-355 Ma, Table 5 and Figs. 12 and 14c) and penecontemporaneous to late mafic dykes (classified as back-arc basalt). Geochronological dating and subsidence analysis of the Paganzo basin of NW Argentina support an initial rift stage basin at the time of the Devonian-Carboniferous boundary (Astini et al., 2009, 2011). Finally, the magmatic system probably migrated westwards (i.e., Precordillera, Frontal Cordillera and Coastal Cordillera), generating mostly I-type calc-alkaline magmatism in the Upper Carboniferous (Fig. 14d).

High-pressure metamorphic rocks with ages of crystallisation and exhumation consistent with this model have been found throughout this part of the western margin of Gondwana: in the Cordillera Frontal at $33^{\circ} \mathrm{S}$ (390-353 Ma, Willner et al., 2011) and in the North Patagonian Andes at $41^{\circ} \mathrm{S}$ (392-350 Ma, Martínez et al., 2011). The roll-back process would lead to extension in the adjacent orogen, creating the necessary space for exhumation of deeper crustal levels as well as interrupting the convergence (lister and Forster, 2009 and references therein).

\section{Conclusions}

Whole-rock chemical composition together with isotopic and geochronological data demonstrates that the Cerro La Gloria pluton crystallised from a sub- to mid-alkaline A-type magma emplaced during Early Carboniferous times. The pluton has characteristics typical of those that crop out in the TIPA shear zone: circular form, sharp contacts and a mineralogy consisting of albite + microcline + quartz + biotite $+\mathrm{Fe}$-edenite + epidote + titanite + allanite. The Cerro La Gloria magma shows only a small contribution from evolved crustal material.

The main conclusions that follow from regional comparisons are:

(1) Early Carboniferous A-type granitoids in the Eastern Sierras Pampeanas represent a distinctive magmatic episode. They exhibit longitudinal chemical (i.e., $\mathrm{K}$, Th and $\mathrm{Rb}$ ) and $\mathrm{Nd}$-isotope variations that can be interpreted as due to lithospheric extension and the contribution of mantle-derived sources as far as the Sierra de Famatina $\left(\sim 68^{\circ} \mathrm{W}\right)$. Farther inland higher concentrations of incompatible elements correlate with decreasing $\varepsilon N d t$ values, indicating increased crustal contamination and probable thickening of the crust.

(2) Geochemical data for the mafic dykes associated with the Early Carboniferous granitoids show that they can be classified as back-arc basin basalts, implying that they formed from a MORB-like primary magma with addition of a subduction component during upwelling and decompression of the (delaminated?) metasomatised lithosphere. From field evidence, they are synchronous or late with respect to the A-type magmatism. Geochronological data should be obtained to restrict this event.

(3) Lithospheric stretching is seen as the probable trigger for generation of the K-high calc-alkaline to shoshonitic magmatism in the studied region of the Eastern Sierras Pampeanas, and it occurred in response to foundering of a Devonian subducted flat-slab beneath the continent. These rocks show a mineralogical and isotopic zonation: to the west (i.e., Sierra de Famatina) there is a minimal contribution from evolved upper crustal material and the granitoids are amphibole-bearing, whereas to the east (i.e., Sierras de Velasco and Ancasti) the crust had a more important contributory role, biotite is the only mafic mineral and primary muscovite appears accompanied by small S-type granitoids.

In general we conclude that the origin of the Early Carboniferous magmatism in the Eastern Sierras Pampeanas (at least in the studied region) could be related to accretion/roll-back along the west Gondwana margin. The region was an important setting for crustal growth by the 
incorporation of juvenile material ultimately derived from the mantle, albeit probably via melting of underplated basalt. Considering the wide compositional range of granites associated with such a complex orogen we should be careful how we use A-/I-type or syn-/post-collision terminology.

\section{Acknowledgementw}

Funds were provided by Spanish MICINN grant CGL2009-07984/ BTE, a CAM-Santander grant GR58/08 and an Argentinean PICГ 1009 and UNLaR 7868-2009 grants. Pablo Alasino thanks Fernando Colombo for its help in amphibole classification. We thank Arne Willner, Patricia Wood Dickerson and an anonymous for their very constructive reviews that significantly improved the manuscript and Eric Tohver for editorial assistance. Pablo Alasino thanks Carlos Bustamante and Sergio de La Vega for technical support.

\section{Appendix A. Supplementary data}

Supplementary data to this article can be found online at doi: 10 . 1016/j.gr.2011.12.011.

\section{References}

Abdel Rahman, A.M., 1994. Nature of biotites from alkaline, calc-alkaline and peraluminous magmas. Journal of Petrology 35, 525-541.

Aceñolaza, F.G., Miller, H., Toselli, A.J., 1996. Geología del Sistema de Famatina. In: Aceñolaza, F.G., Miller, H., Toselli, A.J. (Eds.), Geología del Sistema de Famatina: Münchner Geologische Hefte, Reihe A, 19. 412 pp.

Alasino, P.H., Dahlquist, J.A., Galindo, C., Casquet, C, Saavedra, J., 2010. Andalusite and Na- and Li-rich cordierite in the La Costa pluton, Sierras Pampeanas, Argentina: textural and chemical evidence for a magmatic origin. International Journal of Earth Sciences 99, 1051-1065.

Astini, R.A, Collo, G., Martina, F., 2007. Ordovician K-bentonites in the upper-plate active margin of Western Gondwana, (Famatina ranges): stratigraphic and palaeogeographic significance. Gondwana Research 11,311-325.

Astini, R.A., Martina, F., Ezpeleta, M., Dávila, F.M., Cawood, P.A., 2009. Chronology from rifting to foreland basin in the Paganzo Basin (Argentina), and a reapprisal on the 'Eo- and Neohercynian' tectonics along Westem Gondwana. XII Congreso Geolögico Chileno, Actas, S9-010, pp. 40-43. Santiago.

Astini, RA, Martina, F., Dávila, F.M., 2011. La Formación Ios Llantenes en la Precordillera de Jagüé (Ia Rioja) y la identificación de un episodio de r rifting en la evolución de las cuencas del Paleozoico superior en el oeste argentino. Andean Geology 38, 245-267.

Avila, J.C., Rubinstein, N., Morello, O., Fogliata, A, 2008. Edad y caracterización de una mica de litio asociada a un sistema de greisen en Mina la Rosario, Sierra de Fiambalá, Catamarca. Revista de la Asociación Geológica Argentina 63, 43-48.

Báez, M.A. Basei, M.A., Toselli, A.J., Rossi,J.N., 2004 Geocronología de granitos de la sierra de Velasco (Argentina): reinterpretación de la secuencia magmática. Actas Simposio 40 años de geocronología en Brasil, San Pablo, Brasil, p. 85.

Basei, M., Ramos, V.A, Vujovich, G.I., Poma, S., 1998. El basamento metamórfico de la Cordillera Frontal de Mendoza: nuevos datos geocronólogicos e isotópicos. X Congreso Latinoamericano de Geología yVI Congreso Nacional de Geología Económica, Buenos Aires, Actas, 2, pp. 412-417.

Barbarin, B., Didier, J., 1992. Genesis and evolution of mafic microgranular enclaves through various types of interaction between coexisting felsic and mafic magmas. Transactions of the Royal Society of Edinburgh: Earth Sciences 83, 145-153.

Caminos, R., 1972. El perfil geológico de la Cordillera entre los $28^{\circ} 00^{\prime}$ y $28^{\circ} 30^{\prime}$ de latitud sur, provincial de La Rioja, República Argentina. Revista de la Asociación Geológica Argentina 27, 71-83.

Caminos, R., 1979a. Sierras Pampeanas Noroccidentales. Salta, Tucumán, Catamarca, Ia Rioja y San Juan. Segundo Simposio de Geología, Regional Argentina: Academia Nacional de Ciencias de Córdoba, I, pp. 225-291.

Caminos, R., 1979b. Cordillera frontal. In: Turner, J.C.M. (Ed.), Geología Regional Argentina: Academia Nacional de Ciencias, I, pp. 397-453.

Caminos, R., Cordani, U.G., Linares, E., 1979. Geología y geocronología de las rocas metamórficas y eruptivas de la Precordillera y Cordillera Frontal de Mendoza, República Argentina. II Congreso Geológico Chileno, Actas, 1, pp. 43-61.

Casquet, C., Rapela, C.W., Baldo, E.G., Pankhurst, R.J., Dahlquist, J., González Casado, J.M.†., Fanning, M., Saavedra, J., 2008. Allochthoneity of the Argentine Precordillera terrane: an alternative to current paleogeographical models. In symposium: "Neoproterozoic to early Palaeozoic orogenic belts of South America": International Geological Congress, Oslo, 33. Conference abstract.

Chappell, B.W., White, A.J.R., 1992. I- and S-type granites in the Iachlan Fold Belt. Transactions of the Royal Society of Edinburgh: Earth Sciences 83, 1-26.

Cingolani, C., Varela, R, Dalla Salda, L., Kawashita, K., 1993. Los granitoides del Cerro Veladero, río de la Troya, provincia de La Rioja: estudio geocronológico e implicancias tectónicas. XII Congreso Geológico Argentino y II Congreso de Exploración de Hidrocarburos, Buenos Aires, Actas, 4, pp. 68-74. 2003. The Rodeo Bordalesa Tonalite, San Rafael Block (Argentina): geochemical and isotopic age constrains. X Congreso Geológico Chileno, Concepción. $10 \mathrm{p} \mathrm{Ab}$ stracts, CD ROM.

Collins, W.J., 2002. Hot orogens, tectonic switching, and creation of continental crust. Geology 30, 535-538.

Conci, J.D., Dávila, F.M., Astini, R.A., Martino, RD., 2001. Ia faja de deformación de Chuschín $\left(29^{\circ} 17^{\prime} S\right)$, sierra de Famatina, provincia de Ia Rioja, Argentina. Asociación Geológica Argentina Serie D-5, 117-120.

Currie, C.A. Beaumont, C. Huismans, RS., 2007. The fate of subducted sediments: a case for backarc intrusion and underplating. Geology 35, 1111-1114.

Dahlquist, J.A., Pankhurst, R.J., Rapela, C.W., Casquet, C., Fanning, C.M., Alasino, P., Baez, F.M., 2006. The San Blas Pluton: an example of Carboniferous plutonism in the Sierras Pampeanas, Argentina. Journal of South American Earth Sciences 20, 341-350.

Dahlquist, J.A., Pankhurst, R.J., Rapela, C.W., Galindo, C., Alasino, P., Fanning, C.M., Saavedra, J., Baldo, E., 2008. New SHRIMP U-Pb data from the Famatina complex: constraining Early-Mid Ordovician Famatinian magmatism in the Sierras Pampeanas, Argentina. Geologica Acta 6, 319-333.

Dahlquist, J.A., Alasino, P.H., Eby, G.N., Galindo, C, Casquet, C, 2010. Fault controlled Carboniferous A-type magmatism in the proto-Andean foreland (Sierras Pampeanas, Argentina): geochemical constraints and petrogenesis. Lithos 115, 65-81.

de los Hoyos, C.R., Willner, A.P., Larrovere, M.A, Rossi, J.N., Toselli, A.J., Basei, M.A.S., 2011. Tectonothermal evolution and exhumation history of the Paleozoic ProtoAndean Gondwana margin crust: the Famatinian Belt in NW Argentina. Gondwana Research 20, 309-324.

De Paolo, D.J., Linn, A.M., Schubert, G., 1991. The continental crustal age distribution: methods of determining mantle separation ages from Sm-Nd isotopic data and application to the Southwestern United States. Journal of Geophysical Research 96 , 2071-2088.

Dessanti, R., Caminos, R, 1967. Edades potasio-argón y posición estratigráfica de algunas rocas ígneas y metamórficas de la Precordillera, Cordillera Frontal y Sierras de San Rafael, provincia de Mendoza. Revista de la Asociación Geológica Argentina 22, $135-162$.

Eby, G.N., 1992. Chemical subdivision of the A-type granitoids: petrogenetic and tectonic implications. Geology 20, 641-644.

Farahat, E.S., El Mahallawi, M.M., Hoinkes, G., Abdel Aal, A.Y., 2004. Continental back-arc basin origin of some ophiolites from the Eastern Desert of Egypt. Mineralogy and Petrology 82,81-104.

Frigerio, P.V., Cingolani, C.A., Chemale Jr., F., Basei, M.A.S., 2010. U-Pb ages of the subduction related Potrerillos pluton, northern Cuyania terrane, La Rioja Province, Argentina. VII South American Symposium on Isotope Geology, Brasília, pp. 162-165.

Fryer, P., Sinton, J.M., Philpotts, J.A., 1981. Basaltic glasses from the Mariana Trough. Initial reports of the Deep Sea Drilling Project. US Government Printing Office 60 , 601-609.

Gorczyk, W., Willner, A.P., Gerya, T.V., Connolly, J.A., Burg, J.-P., 2007. Physical controls of magmatic productivity at Pacific-type convergent margins: numerical modeling. Physics of the Earth and Planetary Interiors 163, 209-232.

Gregori, D.A., Fernández-Turiel, J.L., Iópez-Soler, A, Petford, N., 1996. Geochemistry of Upper Palaeozoic-Lower Triassic granitoids of the Central Frontal Cordillera $\left(33^{\circ} 10^{\prime}-33^{\bullet} 45^{\prime}\right)$, Argentina. Journal of South American Earth Sciences 9, 141-151.

Grissom, G.C, Debari, S.M., Snee, L.W., 1998. Geology of the Sierras de Fiambalá, northwestern Argentina: implications for Early Palaeozoic Andean tectonics. In: Pankhurst, R.J., Rapela, C.W. (Eds.), The Proto-Andean Margin of Gondwana: Journal of the Geological Society, London, Special Publications, 142, pp. 297-323.

Grosse, P., Söllner, F., Baéz, M.A., Toselli, A.J., Rossi,J.N., de la Rosa, J.D., 2009. Iower Carboniferous post-orogenic granites in central-eastern Sierra de Velasco, Sierras Pampeanas, Argentina: U-Pb monazite geochronology and $\mathrm{Sr}-\mathrm{Nd}$ isotopes. International Journal of Earth Science 98, 1001-1025.

Hervé, F., Munizaga, F., Parada, M.A., Brook, M., Pankhurst, R.J., Snelling, N.J., Drake, R., 1988. Granitoids of the Coast Range of central Chile: geochronology and geologic setting. Journal South American Earth Science 1, 185-194.

Höckenreiner, M, Söllner, F., Miller, H., 2003. Dating the TIPA shear zone: an early Devonian terrane boundary between the Famatinian and Pampean systems (NW Argentina). Journal of South America Earth Sciences 16, 45-66.

Jarosewich, E., Nelen, J.A., Norberg, J.A, 1980. Reference samples for electron microprobe analysis. Geostandards Newsletter 4, 43-47.

Johnson, D.M., Hooper, P.R., Conrey, RM., 1999. XRF analysis of rocks and minerals for major and trace elements on a single low dilution Li-tetraborate fused bead. Advances in X-ray Analysis 41, 843-867.

Johnson, M.C., Plank, T., 1999. Dehydration and melting experiments constrain the fate of subducted sediments. Geochemistry, Geophysics, Geosystems 1 Paper Number 1999GC000014

Klein, E.M., Iangmuir, C.H., 1987. Global correlations of ocean ridge basalt chemistry with axial depth and crustal thickness. Journal of Geophysical Research 92 , 8089-8115.

Knüver, M., 1983. Dataciones radimétricas de rocas plutónicas y metamórficas. In: Aceñolaza, F.G., Miller, H., Toselli, J. (Eds.), Geología de la sierra de Ancasti, Münstersche Forschungen zur Geologie und Pälaontologie: Münster. Heft, 59, pp. 201-218

Konopelko, D., Biske, G., Seltmann, R., Eklund, O., Belyatsky, B., 2007. Hercynian postcollisional A-type granites of the KokshaalRange, Southern Tien Shan, Kyrgyzstan. Lithos 97, 140-160.

Kretz, R, 1983. Symbols for rock-forming minerals. American Mineralogist 68, 277-279. 
Leake, B.E., Woolley, A.R., Arps, C.E.S., Birch, W.D., Gilbert, M.C., Grice, J.D., Hawthorne, F.C., Kato, A. Kisch, H.J., Krivovichev, V.G., Linthout, K., Laird, J., Mandarino, J.A Maresch, W.V, Nickel, E.H., Rock, N.M.S., Schumacher, J.C., Smith, D.C., Stephenson, N.C.N., Ungaretti, L., Whittaker, E.J.W., Youzhi, G., 1997. Nomenclature of amphiboles: report of the Subcommittee on Amphiboles of the International Mineralogical Association, Commission on New Minerals and Mineral Names. The Canadian Mineralogist 35, 219-246.

Li, Z.X, Li, X., 2007. Formation of the $1300-\mathrm{km}$-wide intracontinental orogen and postorogenic magmatic province in Mesozoic South China: a flat-slab subduction model. Geology 35, 179-182.

Lira, R., Kirschbaum, A.M., 1990. Geochemical evolution of granites from the Achala batholith of the Sierras Pampeanas, Argentina. In: Kay, S.M., Rapela, C.W. (Eds.), Plutonism from Antarctica to Alaska: Geological Society of America Special Paper, 241, pp. 67-76.

Lister, G., Forster, M., 2009. Tectonic mode switches and the nature of orogenesis. Lithos $113,274-291$.

López, V., Gregori, D.A, 2004. Provenance and evolution of the Guarguaraz Complex Cordillera Frontal, Argentina. Gondwana Research 7, 1197-1208.

López de Luchi, M.G., Rapalini, A.E., Siegesmund, S., Steenken, A., 2004. Application of magnetic fabrics to the emplacement and tectonic history of Devonian granitoids in central Argentina. In: Martín-Hernández, F., Lüneburg, F., Aubourg, C., Jackson, M. (Eds.), Magnetic Fabric: Methods and Applications: Geological Society, London, Special Publications, 238, pp. 447-474.

Lucassen, F., Franz, G., Thirlwall, M.F., Mezger, K., 1999. Crustal recycling of metamorphic basement: Late Palaeozoic granitoids of northern Chile $\left(22^{\circ} \mathrm{S}\right)$. Implications for the composition of the Andean crust. Journal of Petrology 40, 1527-1551.

Llambias, E.J., Sato, A.M., 1995. El batolito de Colangüil: transición entre orogénesis y anorogénesis. Revista de la Asociación Geológica Argentina 50, 111-131.

Llambías, E.J, Sato, A.M., Ortiz Suárez, A., Prozzi, C, 1998. The granitoids of the Sierra de San Luis. In: Pankhurst, RJ., Rapela, C.W. (Eds.), The Proto-Andean margin of Gondwana: Geological Society of Iondon, Special Publications, 142, pp. 325-341.

Martina, F., Viramonte, J.M., Astini, R.A., Pimentel, M.M., Dantas, E., 2011. Mississippian volcanism in the south-central Andes: new U-Pb SHRIMP zircon geochronology and whole-rock geochemistry. Gondwana Research 19, 524-534.

Martínez, J.C., Dristas, J.A., Massonne, H.-J., 2011. Palaeozoic accretion of the microcontinent Chilenia, North Patagonian Andes: high-pressure metamorphism and subsequent thermal relaxation. International Geology Review 1-19 iFirst article.

McBride, S.L., Caelles, J.C., Clark, A.H., Farrar, E., 1976. Paleozoic radiometric age prov inces in the Andean basement, latitudes $25^{\circ}-30^{\circ} \mathrm{S}$. Earth and Planetary Science Letters 29, 373-383.

McGuire, A.V., Francis, C.A., Diar, M.D., 1992. Mineralstandards for electron microprobe analysis of oxygen. American Mineralogist 77, 1087-1091

Miller, C.F., McDowell, S.M., Mapes, R.W., 2003. Hot and cold granites? Implications of zir con saturation temperatures and preservation of inheritance. Geology 31, 529-532.

Morello, O., Rubinstein, N., 2000. Los diques alcalinos y subalcalinos del flanco occidental de la sierra de Fiambalá, Catamarca. Revista de la Asociación Geológica Argentina 55 245-250.

Müller, D., Rock, N.M.S., Groves, D.I., 1992. Geochemical discrimination between shoshonitic and potassic volcanic rocks in different tectonic settings: a pilot study. Mineralogy and Petrology 46, 259-289.

Nabelek, P.L, Liu, M., 2004. Petrologic and thermal constraints on the origin of leucogranites in collisional orogens. Transactions of the Royal Society of Edinburgh: Earth Science $95,73-85$.

Nelson, D.R., 1992. Isotopic characteristic of potassic rocks. Evidence for the involvement of subducted sediment in magma genesis. Lithos 28, 403-420.

Pankhurst, R.J., Rapela, C.W., Saavedra, J., Baldo, E., Dahlquist, J., Pascua, I., Fanning C.M., 1998. The Famatinian magmatic arc in the southern Sierras Pampeanas. In Pankhurst, R.J., Rapela, C.W. (Eds.), The Proto-Andean Margin of Gondwana: Geological Society of London, Special Publications, 142, pp. 343-367.

Pankhurst, R.J., Rapela, C.W., Fanning, C.M., 2000. Age and origin of coeval TIG, I-S-type granites in the Famatinian belt of NW Argentina. Transactions of the Royal Society of Edinburgh: Earth Sciences 91, 151-168.

Parada, M.A., Nyström, J.O., Levi, B., 1999. Multiple sources for the Coastal Batholith of central Chile ( $\left.31^{\circ}-34^{\circ} \mathrm{S}\right)$ : geochemical and $\mathrm{Sr}-\mathrm{Nd}$ isotopic evidence and tectonics implications. Lithos 46, 505-521.

Pearce, J.A., 1982. Trace element characteristics of lavas from destructive plate margins. In: Thorpe, RS. (Ed.), Andesites. John Wiley and Sons, New York, pp. 525-548.

Pearce, J.A. Harris, N.B.W., Tindle, A.G., 1984. Trace element discrimination diagrams for the tectonic interpretation of granitic rocks. Journal of Petrology 25, 956-983.

Pearce, J.A., Peate, D.W., 1995. Tectonic implications of the composition of volcanic arc lavas. Annual Review of Earth and Planetary Sciences 23, 251-285.

Pearce,J.A., Stern, RJ., 2006. The origin of back-arc basin magmas: trace element and isotope perspectives. American Geophysical Union Geophysical Monograph 166, 63-86.

Peccerillo, A., Taylor, S.R., 1976. Geochemistry of Eocene calc-alkaline volcanic rocks from the Kastamonu area, Northem Turkey. Contributions to Mineralogy and Petrology 58 63-81.

Ramos, V.A., Jordan, T.E., Allmendinger, R.W., Mpodozis, C, Kay, S.M., Cortés, J.M. Palma, M.A, 1986. Paleozoic terrains of the central Argentine Chilean Andes. Tectonics 5, 855-880.

Rapela, C.W., Pankhurst, R.J., Casquet, C, Baldo, E., Saavedra, J., Galindo, C., Fanning, M., 1998. The Pampean orogeny of the southern proto-Andes: Cambrian continental collision in the Sierras de Córdoba. In: Pankhurst, R.J., Rapela, C.W. (Eds.), The Proto-Andean Margin of Gondwana: Geological Society of London, Special Publications, 142, pp. 181-217.

Rapela, C.W., Baldo, E.G., Pankhurst, R.J., Fanning, C.M., 2008. The Devonian Achala batholith in the Sierras Pampeanas: F-rich aluminous A-type granites. VI South
American Symposium on Isotope Geology, San Carlos de Bariloche, Argentina: Proceedings in CD-ROM, Paper, 53.

Rapela, C.W., Pankhurst, R.J., Casquet, C., Baldo, E.G., Galindo Francisco, C., Fanning, C.M., Dahlquist, J.A. 2010. The Western Sierras Pampeanas: protracted Grenvilleage history (1330-1030 Ma) of intra-oceanic arcs, subduction-accretion a continental-edge and AMCG intraplate magmatism. Journal of South American Earth Sciences 20, 105-127.

Remesal, M., Fauqué, L., Limarino, C., 2004. Volcanismo calcoalcalino neopaleozoico en la Precordillera de Ia Rioja. Petrología y caracterización litoestratigráfica de la Formación Punta del Agua (Carbonífero Superior-Pérmico Inferior). Revista de la Asociación Geológica Argentina 59, 462-476.

Rittmann, A, 1957. On the serial character of igneous rocks. Egyptian Journal of Geology $1,23-48$.

Saavedra,J., Toselli, A, Rossi, J., Pellitero, E., Durand, F., 1998a. The Early Paleozoic magmatic record of the Famatina System: a review. In: Pankhurst, R.J., Rapela, C.W. (Eds.), The Proto-Andean Margin of Gondwana: Geological Society of London, Special Publications, 142, pp. 283-295.

Saunders, A.D., Tarney, J., 1979. The geochemistry of basalts from a back-arc spreading centre in the east Scotia Sea. Geochimica et Cosmochimica Acta 43, 555-572.

Sessarego, H.L., Amos, A.J., Teixeira, W., Kawashinta, K., Remesal, M.B., 1990. Diques Eocarbónicos en la Precordillera Occidental, margen de las Sierras del Tigre, provincial de San Juan. Revista de la Asociación Geológica Argentina 45, 98-106.

Shin jo, R., Chung, S.L, Kato, Y., Kimura, M., 1999. Geochemical and Sr-Nd isotopic characteristics of volcanic rocks from the Okinawa Trough and Ryuku arc: implication for the evolution of a young intracontinental back arc basin. Journal of Geophysical Research 104, 1059-1068.

Siegesmund, S., Steenken, A. López de Luchi, M.G., Wemmer, K., Hoffmann, A., Mosch S., 2004. The Ias Chacras-Potrerillos batholith (Pampean Ranges, Argentina): structural evidence, emplacement and timing of the intrusion. International Journal of Earth Sciences 93, 23-43.

Sims, J.P., Ireland, T.R., Camacho, A., Lyons, P., Pieters, P.E., Skirrow, R.G., Stuart-Smith, P.G., Miró, R., 1998. U-Pb, Th-Pb and Ar-Ar geochronology from the southern Sierras Pampeanas, Argentina: implications for the Palaeozoic tectonics evolution of the western Gondwana margin. In: Pankhurst, R.J., Rapela, C.W. (Eds.), The Proto-Andean Margin of Gondwana: Geological Society of Iondon, Special Publications, 142 , pp. $259-281$.

Spagnuolo, C.M., Rapalini, A.E., Astini, R.A., 2011. Assembly of Pampia to the SW Gondwana margin: a case of strike-slip docking? Gondwana Research. doi:10.1016 j.gr.2011.02.004

Steenken, A., Siegesmund, S., Wemmer, K., Iópez De Luchi, M.G., 2008. Time constraints on the Famatinian and Achalian structural evolution of the basement of the Sierra de San Luis (Eastern Sierras Pampeanas, Argentina). Journal of South American Earth Sciences 25, 336-358.

Steiger, R.H., Jäger, E., 1977. Subcommission of geochronology: convention on the use of decay constants in geo- and cosmochronology. Earth and Planetary Science Ietters $1,369-371$.

Stuart-Smith, P.G., Miró, R., Sims, J.P, Pieters, P.E., Lyons, P., Camacho, A., Skirrow, R.G., Black, L.P., 1999. Uranium-lead dating of felsic magmatic cycles in the southern $\mathrm{Si}$ erras Pampeanas, Argentina: implications for the tectonic development of the proto-Andean Gondwana margin. In: Ramos, V.A. Keppie, J.D. (Eds.), LaurentiaGondwana connections before Pangea: Geological Society of America Special Publication, 336, pp. 87-114

Sun, S.S., McDonough, W.F., 1989. Chemical and isotopic systematics of oceanic basalts: implications for mantle composition and processes. In: Saunders, A.D., Norry, M.J (Eds.), Magmatism in the Ocean Basins: Geological Society of London, Special Publications, 42, pp. 313-345.

Tera, F., Wasserburg, G., 1972. U-Th-Pb systematics in three Apollo 14 basalts and the problem of initial $\mathrm{Pb}$ in lunar rocks. Earth and Planetary Science Letters 14, 281-304

Thomas, W.A. Astini, R.A. 2003. Ordovician accretion of the Argentine Precordillera terrane to Gondwana: a review. Journal of South American Earth Sciences 16 $67-79$

Tohver, E., Cawood, P.A., Rossello, E.A., Jourdan, F., 2011. Closure of the Clymene Ocean and formation of West Gondwana in the Cambrian: evidence from the Sierras Australes of the southernmost Rio de la Plata craton, Argentina. Gondwana Research doi:10.1016/j.gr.2011.04.001.

Toselli, A. J., Pellitero, E., Saavedra, J., Rossi, J.N., Murata, C., 1996. Granito ÑuñorcoSañogasta. In: Aceñolaza, F.G., Miller, H., Toselli, A.J. (Eds.), Geología del Sistem de Famatina: Münchner Geologische Hefte, Reihe A, 19, pp. 211-21s

Varela, R., Cingolani, C.A., Dalla Salda, L.H. Aragón, E., Teixeira, W, 1993. Las monzodioritas y monzogabros de Cacheuta, Mendoza: edad, petrología e implicancias tectónicas. XII Congreso Geológico Argentino y II Congreso de Exploración de Hidrocarburos, Buenos Aires, Actas, 4, pp. 75-80.

Varela, R., Lopez de Lucchi, M., Cingolani, C., Dalla Salda, L., 1996. Geocronología de gneises y granitoides de la Sierra de Umango, Ia Rioja. Implicancias tectónicas. XIII Congreso Geológico Argentino and III Congreso de Exploración de Hidrocarburos, Buenos Aires, Actas, 3, pp. 519-527.

Varela, R., Sato, A.M., González, P.D., 2002. Metamorfismo y deformación devónicos en la sierra de Umango, Sierras Pampeanas Occidentales, Ia Rioja, Argentina. XV Congreso Geológico Argentino, El Calafate, Actas, 2, pp. 57-63.

Varela, R., Basei, M.A.S., Sato, A.M., Passarelli, C.R., Cavarozzi, C.E., González, P.D., 2004 Nuevos datos isotópicos en la Sierra de Umango, antepaís andino a los $29^{\circ} \mathrm{S}$ : edad del granito Los Guandacolinos. 40 Anos de Geocronología no Brasil, Sao Paulo. Boletim de Resumos 40 Anos de Geocronología no Brasil: Universidade de SaO Paulo, Instituto de Geociéncias, 1, p. 84

Vaughan, A.P.M., Pankhurst, R.J., 2008. Tectonic overview of the West Gondwana mar gin. Gondwana Research 13, 150-162. 
Watson, E.B., Harrison, T.M., 1983. Zircon saturation revisited: temperature and composition effects in a variety of crustal magma types. Earth and Planetary Science Letters 64, 295-304

Whalen, J.B., Currie, K.L., Chappell, B.W., 1987. A-type granites: geochemical characteristics, discrimination and petrogenesis. Contributions to Mineralogy and Petrology 95, 407-419.

Whalen, J.B., Jenner, G.A., Iongstaffe, F.J., Robert, F., Gariepy, C, 1996. Geochemical and isotopic $(\mathrm{O}, \mathrm{Nd}, \mathrm{Pb}$ and $\mathrm{Sr}$ ) constraints on A-type granite petrogenesis based on the $\mathrm{Top}$ sails igneous suite, Newfoundland Appalachians. Journal of Petrology 37, 1463-1489.

Williams, I.S., 1998. U- Th-Pb geochronology by ion microprobe. In: McKibben, M.A. Shanks, W.C. (Eds.), Applications of microanalytical techniques to understanding mineralising processes. Reviews in Economic Geology 7, 1-35.
Willner, A.P., Gerdes, A., Massonne, H.-J., Schmidt, A., Sudo, M., Thomson, S.N., Vujovich, $G, 2011$. The geodynamics of collision of a microplate (Chilenia) in Devonian times deduced by the pressure-temperature-time evolution within part of a collisional belt (Guarguaraz Complex, W-Argentina). Contributions to Mineralogy and Petrology 162, 303-327.

Winchester, J.H., Floyd, P.A, 1977. Geochemical discrimination of different magma series and their differentiation products using immobile elements. Chemical Geology 20,325-343.

Yao-Hui, J., Shao-Yong, J., Kui-Dong, Z., Hong-Fei, L., 2006. Petrogenesis of Late Jurassic Qianlishan granites and mafic dykes, Southeast China: implications for a back-arc extension setting. Geological Magazine 143, 457-474. 